\title{
A combined geochemical and isotopic study of the fluids discharged from the Montecatini thermal system (NW Tuscany, Italy)
}

\author{
F. Capecchiacci ${ }^{\text {a,b,* }}$, F. Tassi ${ }^{\text {a,b }}$, O. Vaselli ${ }^{\text {a,b }}$, G. Bicocchi ${ }^{\text {a }}$, J. Cabassi ${ }^{\text {a,b }}$, L. Giannini ${ }^{\text {a,b }}$, B. Nisi ${ }^{\text {c }}$, \\ G. Chiocciora ${ }^{\mathrm{d}}$
}

${ }^{a}$ Department of Earth Sciences, University of Florence, Via La Pira, 4, 50121 Florence, Italy

${ }^{\mathrm{b}}$ CNR-IGG Institute of Geosciences and Earth Resources, Via La Pira, 4, 50121 Florence, Italy

${ }^{\text {c } C N R-I G G ~ I n s t i t u t e ~ o f ~ G e o s c i e n c e s ~ a n d ~ E a r t h ~ R e s o u r c e s, ~ V i a ~ M o r u z z i, ~ 1, ~} 56124$ Pisa, Italy

d Studio Tecnico Signa, Via Erta del Castello, 4, 50059 Florence, Italy

\section{A R T I C L E I N F O}

\section{Article history:}

Available online 26 March 2015

Editorial handling by Elisa Sacchi

\begin{abstract}
A B S T R A C T
The thermo-mineral fluids discharges of Montecatini Terme (Northern Apennines, Tuscany, Italy) have been exploited since the Roman times and despite the fact that this thermal complex is one of the biggest in Europe, the most recent geochemical investigations were published almost 40 years ago. To fill this gap, in this paper a detailed geochemical and isotopic investigation on the main thermal springs and wells from the Montecatini thermal system (MTS) is presented.

The chemical and isotopic features of the Montecatini waters suggested that they are mainly controlled by water-rock interaction processes between meteoric water, permeating at depth from the surrounding reliefs (up to $800 \mathrm{~m}$ a.s.l.), and the Triassic evaporites (Burano Formation) belonging to the Tuscan sedimentary series. The local stratigraphic and tectonic framework favors an efficient recharge of the hydrothermal reservoir by the meteoric precipitation from a large catchment area and this aspect plays a fundamental role for the longevity of the Montecatini thermal spas, notwithstanding the huge amount of thermal water exploited. The ${ }^{3} \mathrm{H}$ values indicated that the thermal waters are likely related to a relatively long (>50 years) fluid circulation pattern. Approaching the surface, thermal and saline waters mix with cold and low TDS (Total Dissolved Solids) waters hosted in short, shallow aquifer(s), whose chemistry is dictated by the interaction of rain waters with silico-clastic rocks of low solubility. Geothermometric estimations in the $\mathrm{F}^{-}-\mathrm{SO}_{4}^{2-}-\mathrm{HCO}_{3}^{-}$system suggested the occurrence of a main fluid reservoir at $T \geqslant 80-95^{\circ} \mathrm{C}$ and $\mathrm{PCO}_{2} \sim 0.5$ bars. Such $\mathrm{CO}_{2}$ pressure is consistent with values estimated for other thermal springs from central-southern Tuscany, being $\mathrm{CO}_{2}$ basically supplied by a deep source. Nevertheless, $\delta^{13} \mathrm{C}_{-} \mathrm{CO}_{2}$ and $\delta^{13} \mathrm{C}$-TDIC values were lower than those expected for a mantle/thermometamorphic $\mathrm{CO}_{2}$ source. This can be explained by: (i) isotopic fractionation occurring during calcite precipitation and/or (ii) mixing with biogenically derived gases, occurring at relatively shallow depth.
\end{abstract}

(c) 2015 Elsevier Ltd. All rights reserved.

\section{Introduction}

The Peri-Tyrrhenian sector of central Italy hosts the most important geothermal fields of Italy (Larderello, Mt. Amiata, Latera and Cesano), which are characterized by fluid reservoirs with temperatures $>250{ }^{\circ} \mathrm{C}$ (e.g. Funiciello et al., 1979; Bertrami et al., 1984; Cavarretta et al., 1985; Duchi et al., 1986; Minissale, 1991). Besides these systems, partly related to the Pliocene to Quaternary magmatism that affected the western part of Central Italy, a large number of thermal, mineral and cold springs, fed by

\footnotetext{
* Corresponding author at: Department of Earth Sciences, University of Florence, Via La Pira, 4, 50121 Florence, Italy. Tel.: +39 0552757507.

E-mail address: francesco.capecchiacci@unifi.it (F. Capecchiacci).
}

a regional aquifer hosted within Mesozoic carbonates, also occur (e.g. Bencini et al., 1977; Minissale and Duchi, 1988; Minissale et al., 1997a; Minissale, 2004; Frondini, 2008; Frondini et al., 2009; Chiodini et al., 2013). Natural fluid emissions in the sedimentary domain are strongly controlled by regional tectonics, being mostly located at the boundaries of the carbonate outcrops and along faults bordering the NW-SE post-orogenic intraApenninic basins (e.g. Minissale et al., 2000; Minissale, 2004). In southern Tuscany, emerging waters are commonly associated with $\mathrm{CO}_{2}$-rich gases, whereas in northern Tuscany $\mathrm{N}_{2}$ or $\mathrm{CH}_{4}$ are the dominant gas compounds (Bencini et al., 1977; Bencini and Duchi, 1981; Arrigoni et al., 1982; Minissale et al., 2000). In the Montecatini area (NW sector of Tuscany; Fig. 1), thermal springs have been used for therapies and medical treatments since the 


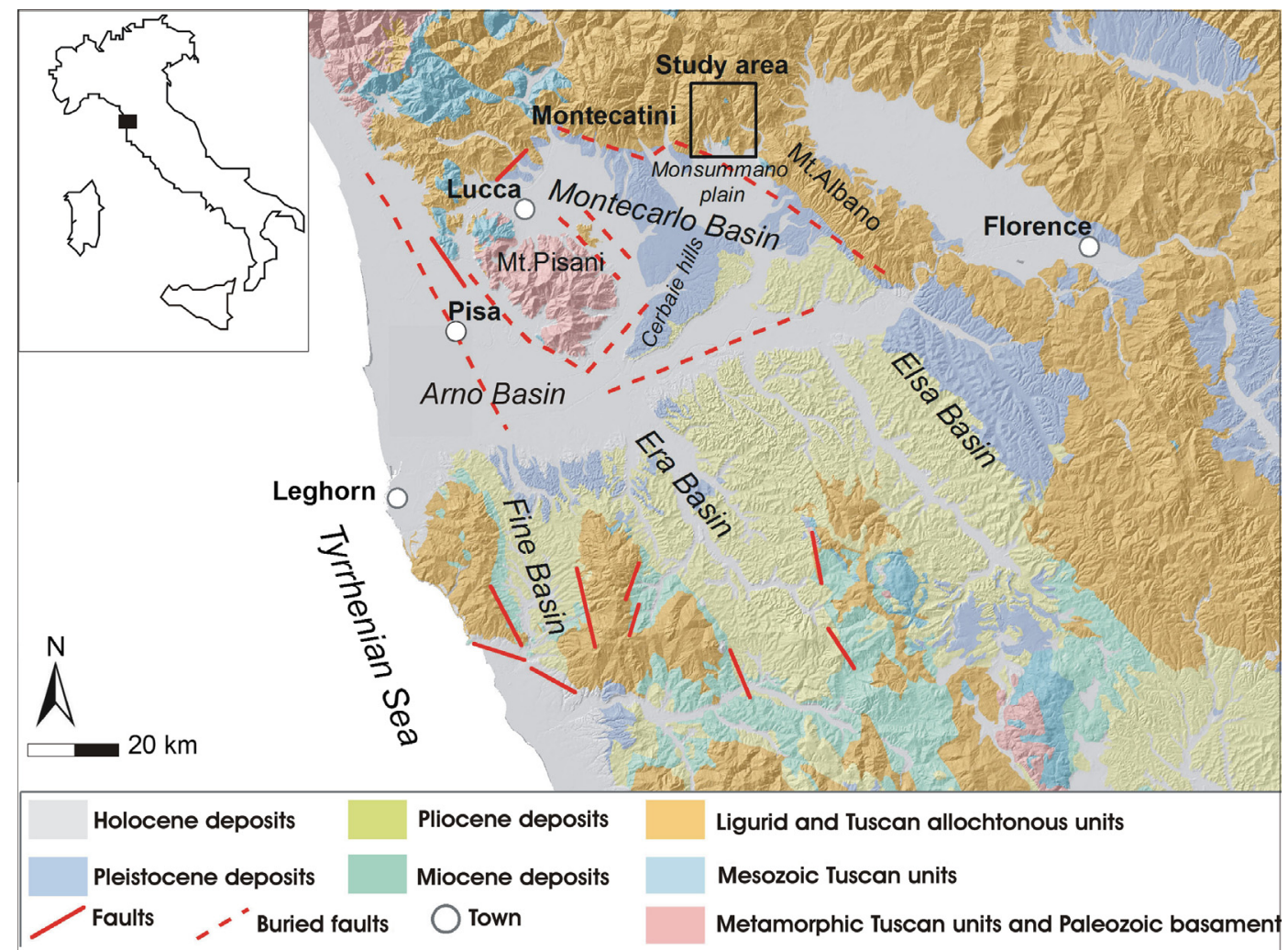

Fig. 1. Geostructural schematic map of central Tuscany and location of the study area.

Roman times, as testified by marble structures and pagan statues found during the archaeological excavations carried out in 1775 . A first description of the chemical-physical features of the Montecatini thermal waters and their therapeutic properties dates back to 1417, when Ugolino da Montecatini, published the treatise "De balneorum Italiae proprietatibus". In the XVIII century, Gran Duca Pietro Leopoldo of Lorena committed the settlement of springs to skillful plumbers, initiating the construction of the Bagno Regio (1773), Terme Leopoldine (1779) and Tettuccio (1779) thermal baths. In the following decades, the Montecatini thermal complex progressively increased its activity and new baths were built such as Gabrielli-La Salute (1830), Torretta (1832), Tamerici (1834), Olivo (1851), Lazzerini (1852), Fortuna (1852), Regina (1855), Scannavini (1870), Grocco (1902) and Giulia (1905). Between the two world wars, two new buildings, Istituto di Cura (1921) and Centro di Studi e Ricerche Scientifiche (1931), were constructed. Currently, it has been estimated that up to $1,700,000$ tourists visit Montecatini each year and approximately 30\% of them benefit of the large variety of thermal and therapeutic treatments (Romei et al., 2012; Romei and Capo, 2014). This makes Montecatini spa one of the most important thermal complexes in Europe.

A first geochemical model for the origin of the Montecatini thermo-mineral waters suggested the occurrence of a single deep fluid reservoir, whose chemical features were dictated by the dissolution of Triassic evaporitic rocks (Canavari, 1924). Geochemical evidences, supporting the occurrence of a mixing process between thermo-mineral waters from a deep reservoir and waters from a shallow aquifer, both of meteoric origin, were then provided in the following decades (Trevisan, 1951, 1954; Carobbi and Cipriani, 1954; Coradossi and Martini, 1965; Brandi et al., 1967; Martini, 1968).

In spite of the importance of this thermal system, to the best of our knowledge no detailed geochemical and isotopic studies of the
Montecatini thermal system have been realized and only in the sixties the latest geochemical data were published in scientific journals.

In the framework of a scientific cooperation between the Montecatini Terme Ltd. and the Department of Earth Sciences (University of Florence) 8 sampling campaigns in the Montecatini area were carried out in 2013 and 2014 during which 31 waters and 15 dissolved gases were collected. Major, minor and trace compounds of waters and dissolved gases, as well as the main isotopic parameters, i.e. ${ }^{18} \mathrm{O} /{ }^{16} \mathrm{O},{ }^{2} \mathrm{H} /{ }^{1} \mathrm{H},{ }^{34} \mathrm{~S} /{ }^{32} \mathrm{~S}, \delta^{13} \mathrm{C}$-TDIC (Total Dissolved Inorganic Carbon) and ${ }^{3} \mathrm{H}$ in waters and $\delta^{13} \mathrm{C}$ in dissolved $\mathrm{CO}_{2}$, were analyzed. In the present paper, this new geochemical database was used to construct an updated geochemical model of the Montecatini thermal system (hereafter, MTS), with the main aim to provide insights into the geochemical processes, which control the chemistry of the circulating fluids.

\section{Geotectonic setting}

The structure of the Northern Apennines represents an orogenic chain originated by collision and subduction between continental margin of the Adriatic microplate and the European plate during the Tertiary (Molli, 2008). In Neogene-Quaternary, the inner edge of the Northern Apennines was affected by the formation of NNW-SSE oriented sedimentary controlled by a prevailing extensional tectonic regime associated with the opening of Tyrrhenian Sea (Patacca et al., 1990; Carmignani et al., 1994), spaced out by compressive phases (Boccaletti et al., 1992; Cerrina Feroni et al., 2004).

Montecatini Terme is located along the northeastern margin of the Montecarlo Basin (Cantini et al., 2001) (Fig. 1), which is limited by the Mt. Albano ridge to the east, and that of the Mts. Pisani to the west, through high-angle NW-SE oriented fault systems. 
The study area is at the foothill of the Northern Apenninic chain, while to the south it is delimited by the River Arno basin. The Montecarlo Basin is divided into two sub-basins by the Cerbaie hills: (i) Lucca and (ii) Monsummano-Montecatini plains (Cantini et al., 2001; Grassi et al., 2011).

The tectonic framework of the Montecatini Terme area consists of a NS-oriented asymmetric anticlinal fold. The most important tectonic structures, which control the spatial distribution of both the Holocene travertine deposits and thermal manifestations, consist of high-angle ESE-WSW, NNW-SSE, and NW-SE-trending normal faults, the latter having caused the uplift of the Cava Maona areas (Fig. 2; Fazzuoli and Maestrelli Manetti, 1973). A schematic geological map is reported in Fig. 2.

The stratigraphic sequence of the Tuscan Domain (Tuscan Nappe) in the area is composed, from the bottom to the top, by the Diaspri (Upper Trias-lower Cretaceous chert-rich layers), Tuscan Scaglia (Cretaceous-Eocene heterogeneous - claystone, calcarenites, silty marls and clays - layers) Maiolica (Upper Titonian-Barremian limestone deposits) and Macigno (Upper Oligocene-lower Miocene sandstone, turbiditic in origin, layers) units, which overlie Jurassic limestone and Triassic evaporite formations (Fazzuoli and Maestrelli Manetti, 1973; Gandin et al., 2000; Cantini et al., 2001). The latter, also known as Burano Formation, is characterized by alternating layers of fetid dolostones, limestones and gypsum-anhydrite strata with intercalations of black marls, clays and shales. Quartz, chalcedony and authigenic albite are accessory phases as well as rare K-feldspar, celestine, halite and native sulfur. In Burano001 borehole, drilled by AGIP in 1956, anhydrite is largely the most abundant mineral (Martinis and Pieri, 1963), whose origin is related to

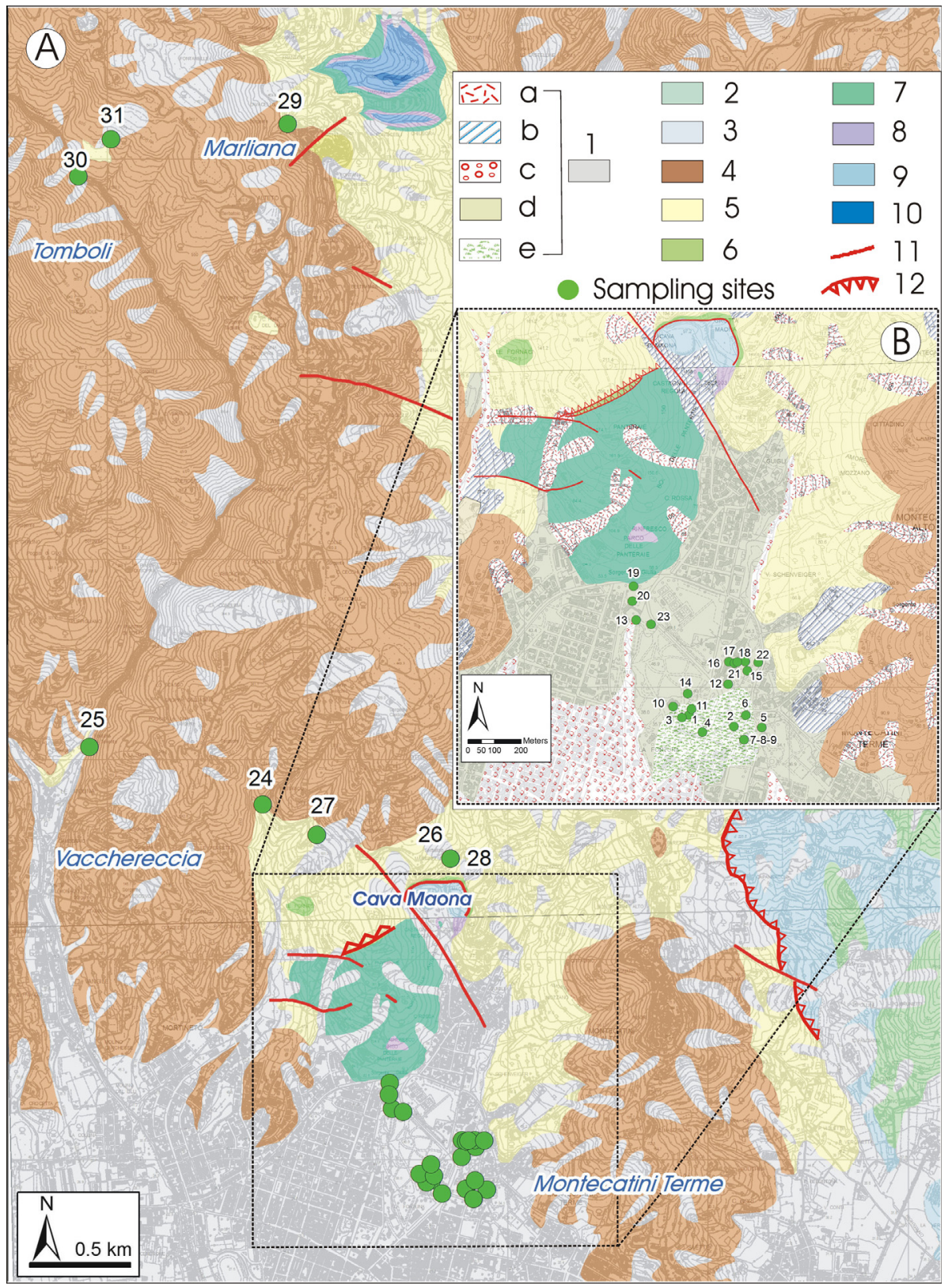

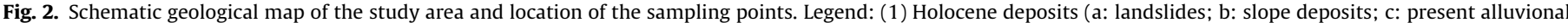

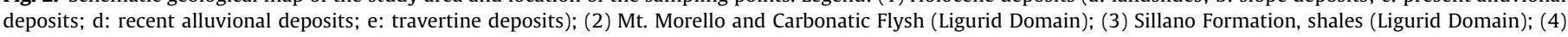

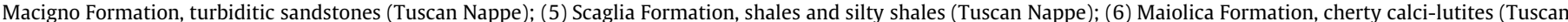

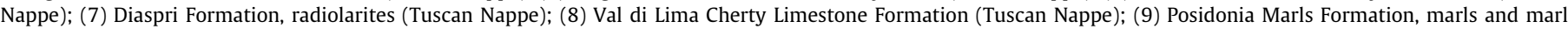

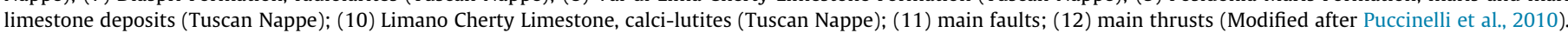


diagenesis/metamorphism (Lugli, 2001) processes that modified the original gypsum layers. The thickness of each layer is between metric and decametric sizes, while that of the entire formation may exceed $1700 \mathrm{~m}$ (Martinis and Pieri, 1963; Lazzarotto et al., 2002). The carbonate and evaporite formations lay on a Palaeozoic basement mostly consisting of quartzites, quartziticmicaceous conglomerates, sandstones and phyllites (Puxeddu, 1984; Lazzarotto et al., 2002).

\section{Materials and methods}

\subsection{Water and gas sampling}

Water samples were collected from 16 thermal springs and 7 wells in the area of Montecatini Terme and from 8 cold springs to the NE (Fig. 2). Dissolved gases were collected from 15 selected waters, however no smell of rotten eggs, typical of $\mathrm{H}_{2} \mathrm{~S}$, was felt close to the sampling points.

Temperature, $\mathrm{pH}$ and total alkalinity were measured in situ. One filtered $(0.45 \mu \mathrm{m})$ and two filtered-acidified (with suprapur $\mathrm{HCl}$ and $\mathrm{HNO}_{3}$, respectively) water samples were collected in polyethylene bottles for the analysis of anions, cations and trace species, respectively. An unfiltered water aliquot was sampled for the determination of water isotopes and ${ }^{13} \mathrm{C} /{ }^{12} \mathrm{C}$ values of the total dissolved inorganic carbon (TDIC) in $125 \mathrm{~mL}$ bottles where few milligrams of $\mathrm{HgCl}_{2}$ were added in the laboratory in order to avoid any bacterial activity able to modify the original carbon isotopic ratio. Three unfiltered water samples $(1000 \mathrm{~mL})$ were collected for the analyses of ${ }^{3} \mathrm{H}$.

Dissolved gases were collected using pre-evacuated $250 \mathrm{~mL}$ Pyrex flasks equipped with Thorion ${ }^{\circledR}$ valve and filled with water up to about 3/4 of their inner volume (Tassi et al., 2008, 2009). The chemical composition was calculated from the composition of the gas phase stored in the headspace of the sampling glass flasks on the basis of (i) gas pressure, (ii) headspace volume and (iii) the solubility coefficients of each gas compound (Whitfield, 1978).

\subsection{Chemical and isotopic analyses of waters}

The analysis of total alkalinity was carried by acid titration against $\mathrm{HCl} 0.01 \mathrm{~N}$ using methyl-orange as indicator. Fluoride, $\mathrm{Cl}^{-}, \mathrm{Br}^{-}, \mathrm{NO}_{3}^{-}, \mathrm{SO}_{4}^{2-}$ and $\mathrm{Ca}^{2+}, \mathrm{Mg}^{2+}, \mathrm{Na}^{+}$, and $\mathrm{K}^{+}$were determined by ion-chromatography (IC) (Metrohm 761 and Metrohm 861, respectively). $\mathrm{B}, \mathrm{Li}^{+}, \mathrm{SiO}_{2}, \mathrm{Sr}^{2+}$, as well as trace elements (i.e. As, $\mathrm{Sb}, \mathrm{Ba}, \mathrm{Ce}, \mathrm{Co}, \mathrm{Cr}, \mathrm{Cu}, \mathrm{Fe}_{\text {tot }}, \mathrm{Mn}, \mathrm{Ni}, \mathrm{Rb}$ and $\mathrm{Zn}$ ) were analyzed at the C.S.A. Ltd. Laboratories (Rimini, Italy) by Inductively Coupled Plasma Mass Spectrometry (ICP-MS) with an Agilent 7500 spectrometer, on the filtered samples acidified with $1 \%$ suprapur $\mathrm{HNO}_{3}$. The analytical errors for IC and ICP-MS were $\leqslant 5$ and $\leqslant 10 \%$, respectively.

The ${ }^{18} \mathrm{O} /{ }^{16} \mathrm{O}$ and ${ }^{2} \mathrm{H} /{ }^{1} \mathrm{H}$ ratios in water (expressed as $\delta^{18} \mathrm{O}-\mathrm{H}_{2} \mathrm{O}$ and $\delta \mathrm{D}-\mathrm{H}_{2} \mathrm{O} \%$ vs. V-SMOW, respectively) were determined by using a Finnigan MAT 252 and an Europa Scientific GEO2020 mass spectrometers, respectively. Oxygen isotopic ratios were analyzed in $\mathrm{CO}_{2}$ added to the water samples using the $\mathrm{CO}_{2}-\mathrm{H}_{2} \mathrm{O}$ equilibration method proposed by Epstein and Mayeda (1953). Hydrogen isotopic ratios were measured on $\mathrm{H}_{2}$ after the reaction of water $(10 \mathrm{~mL})$ with metallic magnesium $(1.6 \mathrm{~g})$ at $440{ }^{\circ} \mathrm{C}$ instead of metallic zinc (Coleman et al., 1982). The analytical uncertainties for $\delta^{18} \mathrm{O}-\mathrm{H}_{2} \mathrm{O}$ and $\delta \mathrm{D}-\mathrm{H}_{2} \mathrm{O}$ ratios were $0.1 \%$ and $1 \%$, respectively.

The $\delta^{13} \mathrm{C}$-TDIC (expressed as \% vs. V-PDB) values were analyzed with a Finnigan MAT 252 mass spectrometer in $\mathrm{CO}_{2}$ recovered after the reaction of $5 \mathrm{~mL}$ of water with $4 \mathrm{~mL}$ of anhydrous $\mathrm{H}_{3} \mathrm{PO}_{4}$ in preevacuated sample holders, which where then left for $12 \mathrm{~h}$ in a thermostatic bath at $25 \pm 0.1^{\circ} \mathrm{C}$. The carbon dioxide was extracted and purified by using the two-step cryogenic (liquid $\mathrm{N}_{2}$ and a mixture of liquid $\mathrm{N}_{2}$ trichloroethylene; Evans et al., 1998; Vaselli et al., 2006) procedure (Salata et al., 2000). The analytical uncertainty for $\delta^{13} \mathrm{C}$-TDIC analysis was $\pm 0.1 \%$. The ${ }^{34} \mathrm{~S} /{ }^{32} \mathrm{~S}$ ratios of $\mathrm{SO}_{4}^{2-}$ (expressed as $\delta^{34} \mathrm{~S}_{-} \mathrm{SO}_{4} \%$ vs. V-CDT) of four selected thermal water samples were analyzed using an EA-IRMS system consisting of a 20-20 isotope ratio mass spectrometer (Europa Scientific, Crewe, UK), equipped with an elemental analyser (Sercon Ltd, Crewe, UK), after the precipitation of $\mathrm{BaSO}_{4}$ with a $\mathrm{BaCl}_{2}$ solution. The solid was separated by centrifugation, dried and transferred into tin capsules, which were combusted at $\approx 1700^{\circ} \mathrm{C}$, to form, among the other gases, $\mathrm{SO}_{2}$. Then, $\mathrm{SO}_{2}$ was separated on a packed $\mathrm{GC}$ column at $45^{\circ} \mathrm{C}$. The isotopic analysis was based on monitoring of $\mathrm{m} / \mathrm{z}$ 48,49 and 50 of $\mathrm{SO}^{+}$produced from $\mathrm{SO}_{2}$ in the ion source. The analytical uncertainly was $\pm 0.3 \%$.

The ${ }^{3} \mathrm{H}$ content (TU, tritium unit; $1 \mathrm{TU}=0.1181 \mathrm{~Bq} / \mathrm{kg}$ for pure water, assuming a half-life of 4540 days for tritium and $6.02205 \times 10^{23}$ as Avogadro constant; Taylor and Roether, 1982) was determined at the Geoisotopical Unit of Public Health, Department of Chemistry (Koper, Slovenia) using Liquid Scintillation Counting (LSC) technique. For this analysis, $500 \mathrm{~mL}$ of water was transferred to a Pyrex container with carborundum ( $\mathrm{SiC})$, at which $250 \mathrm{mg}$ of sodium thiosulfate $\left(\mathrm{Na}_{2} \mathrm{~S}_{2} \mathrm{O}_{3}\right)$ and $500 \mathrm{mg}$ of sodium carbonate $\left(\mathrm{Na}_{2} \mathrm{CO}_{3}\right)$ were added. Blanks and water samples were prepared by means of a distillation apparatus. The analytical uncertainty was $1 \mathrm{~Bq} / \mathrm{m}^{3}$ on $100 \mathrm{~Bq} / \mathrm{m}^{3}(1 \%)$.

\subsection{Chemical and isotopic analysis of dissolved gases}

The composition of the main inorganic compounds $\left(\mathrm{CO}_{2}, \mathrm{~N}_{2}, \mathrm{Ar}\right.$, $\mathrm{CH}_{4}, \mathrm{O}_{2}$ and $\mathrm{Ne}$ ) stored in the headspace of the sampling flasks was carried out using a Shimadzu 15A gas chromatograph (GC) equipped with a $9 \mathrm{~m}$ long molecular sieve column and Thermal Conductivity Detector (TCD). The analysis of $\mathrm{CH}_{4}$ was carried out using a Shimadzu 14A gas chromatograph equipped with a Flame Ionization Detector (FID) and a $10 \mathrm{~m}$ long stainless steel column packed with Chromosorb PAW 80/100 mesh coated with 23\% SP 1700 (Vaselli et al., 2006; Tassi et al., 2008). The analytical error for GC analysis was $\leqslant 5 \%$.

The $\delta^{13} \mathrm{C}$ values of dissolved $\mathrm{CO}_{2}\left(\delta^{13} \mathrm{C}-\mathrm{CO}_{2}\right)$ were calculated from those measured in the separated gas phase stored in the headspace of the dissolved gas flasks $\left(\delta^{13} \mathrm{C}-\mathrm{CO}_{2 \mathrm{STRIP}}\right)$ using the $\varepsilon_{1}$ factor for gas-water isotope equilibrium proposed by Zhang et al. (1995), as follows:

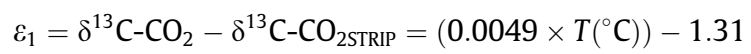

The $\delta^{13} \mathrm{C}-\mathrm{CO}_{2 \mathrm{STRIP}}$ analysis was carried out with a Finnigan Delta $\mathrm{S}$ mass spectrometer, after the two-step extraction and purification procedure, similarly to that used for the analysis of $\delta^{13} \mathrm{C}$-TDIC. Internal (Carrara and S. Vincenzo marbles) and international (NB18 and NBS19) standards were used for estimating the external precision. The analytical uncertainty and the reproducibility were $\pm 0.05 \%$ and $\pm 0.1 \%$, respectively.

\section{Results}

4.1. Chemical and isotopic $\left(\delta^{18} \mathrm{O}-\mathrm{H}_{2} \mathrm{O}, \delta \mathrm{D}-\mathrm{H}_{2} \mathrm{O}, \delta^{34} \mathrm{~S}-\mathrm{SO}_{4}, \delta^{13} \mathrm{C}_{\mathrm{TDIC}}\right.$ and $\left.{ }^{3} \mathrm{H}\right)$ compositions of waters

Outlet temperatures, $\mathrm{pH}$, concentrations of the main solutes (in $\mathrm{mg} / \mathrm{L}$ ) and the TDS (Total Dissolved Solids) values (in $\mathrm{g} / \mathrm{L}$ ) are listed in Table 1.

The MTS water samples have $\mathrm{pH}$ and temperature values ranging from 6.26 to 7.79 and from 12 to $34{ }^{\circ} \mathrm{C}$, respectively. Based on 
Table 1

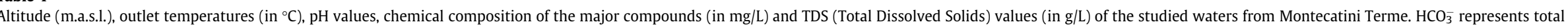
alkalinity as mg $\mathrm{HCO} / \mathrm{L}$.

\begin{tabular}{|c|c|c|c|c|c|c|c|c|c|c|c|c|c|c|c|c|c|c|c|c|c|c|c|}
\hline & Sample & Type & Altitude & UTM E & UTM N & $T$ & $\mathrm{pH}$ & TDS & $\mathrm{HCO}_{3}^{-}$ & $\mathrm{Cl}^{-}$ & $\mathrm{SO}_{4}^{2-}$ & $\mathrm{Na}^{+}$ & $\mathrm{K}^{+}$ & $\mathrm{Mg}^{2+}$ & $\mathrm{Ca}^{2+}$ & $\mathrm{NO}_{3}^{-}$ & $\mathrm{F}^{-}$ & $\mathrm{Br}^{-}$ & B & $\mathrm{Li}^{+}$ & $\mathrm{SiO}_{2}$ & $\mathrm{Sr}^{2+}$ & Group \\
\hline 1 & Cratere Grocco & Spring & 198 & 642592 & 4860882 & 34.2 & 6.59 & 17.4 & 678 & 8590 & 1580 & 5610 & 141 & 123 & 634 & 25 & 7.1 & 3.1 & 3.3 & 3.4 & 35 & 8.7 & $\mathrm{HS}$ \\
\hline 2 & Savi & Spring & 197 & 642762 & 4860839 & 28.0 & 6.57 & 17.2 & 702 & 8400 & 1570 & 5550 & 147 & 122 & 651 & 3.5 & 7.4 & 2.4 & 3.7 & 4.3 & 35 & 10 & HS \\
\hline 3 & Leopoldina Nuova & Well & 187 & 642566 & 4860873 & 34.2 & 6.37 & 17.1 & 641 & 8320 & 1580 & 5590 & 144 & 120 & 629 & 8.7 & 7.5 & 3.1 & 4.0 & 4.9 & 40 & 12 & HS \\
\hline 4 & Leopoldina Vecchia & Well & 188 & 642643 & 4860817 & 34.2 & 6.37 & 16.8 & 660 & 8110 & 1530 & 5590 & 144 & 120 & 629 & 5.6 & 7.2 & 3.3 & 3.8 & 4.7 & 29 & 12 & HS \\
\hline 5 & Campo & Spring & 205 & 642867 & 4860835 & 26.0 & 6.60 & 16.8 & 702 & 8070 & 1430 & 5620 & 140 & 127 & 656 & 5.7 & 6.7 & 2.8 & 3.4 & 3.6 & 38 & 10 & HS \\
\hline 6 & Regina & Spring & 189 & 642807 & 4860881 & 28.0 & 6.38 & 16.5 & 684 & 7860 & 1560 & 5470 & 145 & 120 & 634 & 2.1 & 7.4 & 2.0 & 3.6 & 4.1 & 27 & 11 & HS \\
\hline 7 & La Salute & Well & 204 & 642800 & 4860789 & 21.8 & 6.73 & 16.2 & 629 & 7930 & 1470 & 5210 & 120 & 119 & 662 & 21 & 5.9 & 1.9 & 3.5 & 3.8 & 35 & 10 & HS \\
\hline 8 & Masso & Spring & 204 & 642800 & 4860789 & 18.0 & 7.10 & 15.7 & 629 & 7630 & 1440 & 5090 & 130 & 142 & 613 & 14 & 7.1 & 1.6 & & & & & HS \\
\hline 9 & Grotta & Spring & 204 & 642800 & 4860789 & 19.0 & 6.89 & 15.5 & 635 & 7370 & 1400 & 5120 & 126 & 113 & 625 & 4.4 & 7.3 & 2.7 & 3.2 & 3.7 & 30 & 10 & HS \\
\hline 10 & Tamerici (s) & Spring & 207 & 642532 & 4860914 & 18.0 & 6.89 & 14.5 & 617 & 7050 & 1340 & 4670 & 119 & 101 & 538 & 7.6 & 7.1 & 2.6 & 3.1 & 3.2 & 37 & 10 & HS \\
\hline 11 & Angelo & Well & 210 & 642602 & 4860905 & 19.0 & 6.98 & 11.0 & 544 & 5430 & 850 & 3660 & 115 & 68 & 359 & 8.6 & 3.9 & 1.8 & & & & & IS \\
\hline 12 & Tettuccio & Spring & 191 & 642740 & 4860998 & 25.5 & 6.71 & 9.11 & 538 & 4190 & 915 & 2900 & 81 & 64 & 363 & 21 & 4.3 & 1.9 & 2.5 & 2.7 & 19 & 7.0 & IS \\
\hline 13 & La Torretta & Spring & 186 & 642393 & 4861241 & 23.0 & 6.89 & 9.00 & 483 & 4280 & 851 & 2940 & 65 & 58 & 316 & 6.5 & 4.1 & 1.2 & & & & & IS \\
\hline 14 & Tamerici (w) & Well & 206 & 642587 & 4860963 & 19.0 & 7.25 & 8.84 & 531 & 4110 & 861 & 2940 & 73 & 49 & 261 & 11 & 3.6 & 1.0 & & & & & IS \\
\hline 15 & Papo 1 & Spring & 199 & 642812 & 4861049 & 24.5 & 6.86 & 5.32 & 394 & 2610 & 323 & 1650 & 51 & 37 & 220 & 6.7 & 2.0 & 0.82 & 1.7 & 1.7 & 17 & 4.6 & IS \\
\hline 16 & Baragiola & Well & 209 & 642743 & 4861083 & 20.0 & 7.07 & 5.03 & 428 & 2310 & 441 & 1570 & 42 & 35 & 200 & 3.8 & 2.2 & 0.58 & & & & & IS \\
\hline 17 & Cipollo & Spring & 203 & 642764 & 4861078 & 25.0 & 6.81 & 4.79 & 415 & 2170 & 422 & 1490 & 39 & 34 & 208 & 6.4 & 2.1 & 0.72 & & & & & IS \\
\hline 18 & Papo 2 & Spring & 200 & 642805 & 4861084 & 24.0 & 7.01 & 4.70 & 409 & 2130 & 415 & 1460 & 41 & 32 & 199 & 8.7 & 2.1 & 0.71 & & & & & IS \\
\hline 19 & Giulia & Spring & 185 & 642383 & 4861369 & 26.9 & 6.99 & 3.99 & 403 & 1720 & 345 & 1240 & 37 & 30 & 185 & 3.9 & 1.4 & 0.76 & 1.6 & 1.6 & 18 & 4.1 & IS \\
\hline 20 & Rinfresco & Spring & 184 & 642379 & 4861312 & 26.3 & 6.89 & 3.24 & 379 & 1420 & 251 & 949 & 31 & 24 & 157 & 7.0 & 1.4 & 0.47 & 0.99 & 1.3 & 17 & 3.4 & IS \\
\hline 21 & Padulette 2 & Spring & 202 & 642775 & 4861082 & 19.5 & 6.77 & 2.87 & 358 & 1220 & 254 & 843 & 25 & 22 & 137 & 8.5 & 1.3 & 0.52 & & & & & IS \\
\hline 22 & Padulette 1 & Spring & 201 & 642854 & 4861081 & 20.0 & 7.23 & 2.74 & 379 & 1140 & 218 & 778 & 27 & 20 & 142 & 11 & 1.1 & 0.40 & 0.49 & 0.76 & 17 & 2.3 & IS \\
\hline 23 & Lavandaia & Well & 208 & 642449 & 4861225 & 16.0 & 6.94 & 1.11 & 324 & 340 & 75 & 258 & 13 & 8.1 & 96 & 0.25 & 0.22 & 0.36 & & & & & LS \\
\hline 24 & Orsi & Spring & 195 & 641748 & 4862760 & 16.0 & 7.62 & 0.43 & 237 & 33 & 35 & 26 & 2.9 & 17 & 63 & 11 & 0.31 & 0.05 & & & & & LS \\
\hline 25 & Tenente & Spring & 196 & 640883 & 4863049 & 15.0 & 7.79 & 0.40 & 222 & 25 & 27 & 23 & 2.2 & 17 & 61 & 8.7 & 0.24 & 0.07 & 0.017 & 0.004 & 14 & 0.15 & LS \\
\hline 26 & Maona Media & Spring & 194 & 642686 & 4862491 & 15.0 & 7.44 & 0.37 & 195 & 29 & 35 & 15 & 1.7 & 14 & 56 & 12 & 0.15 & 0.07 & 0.030 & 0.005 & 15 & 0.18 & LS \\
\hline 27 & Melosi & Spring & 192 & 642017 & 4862610 & 14.5 & 7.31 & 0.34 & 195 & 24 & 26 & 20 & 1.0 & 15 & 53 & 9.3 & 0.17 & 0.05 & & & & & LS \\
\hline 28 & Maona Alta & Spring & 194 & 642686 & 4862491 & 14.5 & 7.53 & 0.34 & 196 & 20 & 24 & 15 & 1.3 & 14 & 54 & 11 & 0.31 & 0.05 & & & & & LS \\
\hline 29 & Fonte Becca & Spring & 475 & 641873 & 4866163 & 12.0 & 6.91 & 0.14 & 81 & 11 & 9.0 & 8.9 & 4.5 & 5.3 & 18 & 3.3 & 0.11 & 0.06 & & & & & LS \\
\hline 30 & Lucchesi 1 & Spring & 550 & 640828 & 4865899 & 12.0 & 7.53 & 0.12 & 63 & 10 & 9.5 & 11 & 2.4 & 3.2 & 15 & 0.61 & 0.07 & 0.04 & & & & & LS \\
\hline 31 & Galassi & Spring & 599 & 640991 & 4866085 & 13.0 & 6.26 & 0.09 & 31 & 15 & 7.8 & 11 & 2.2 & 3.2 & 4.8 & 0.09 & 0.06 & 0.02 & 0.040 & 0.005 & 13 & 0.014 & LS \\
\hline
\end{tabular}




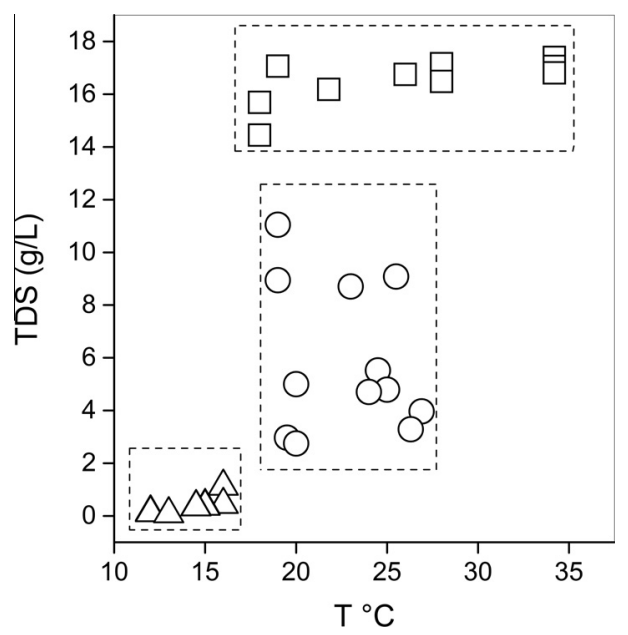

Fig. 3. TDS (in $g / L$ ) vs. Temperature $\left(\right.$ in ${ }^{\circ} \mathrm{C}$ ) binary diagram where the three different groups of the studied waters are distinguished: (i) HS samples (squares); (ii) IS samples (circles) and (iii) LS samples (triangles).

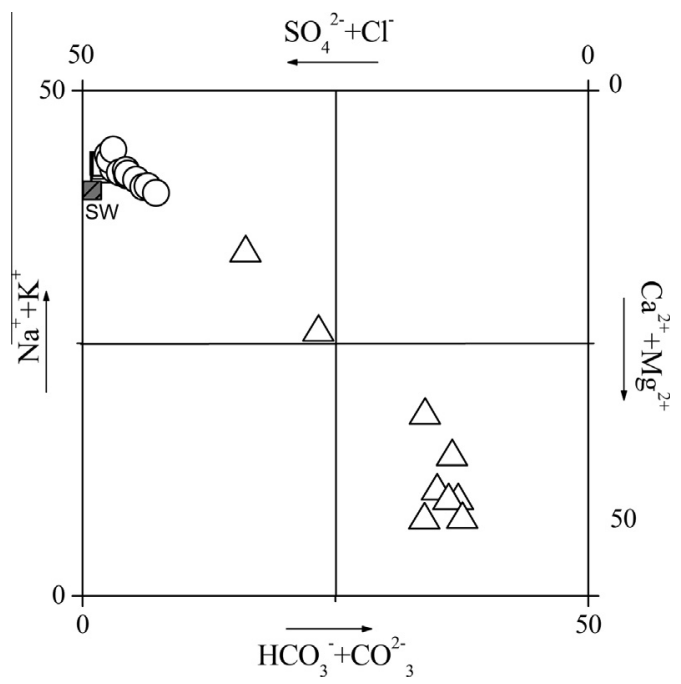

Fig. 4. Distribution of the three different groups of waters in the Langelier-Ludwig diagram: (i) HS samples (squares); (ii) IS samples (circles) and (iii) LS samples (triangles). SW: Sea Water. the TDS values, temperature (Fig. 3) and the chemical composition (Fig. 4), three main groups of waters can be recognized, as follows:

(1) High Salinity (hereafter $H S$ ) waters, which refer to samples from \#1 to \#10 (Table 1). They are characterized by a $\mathrm{Na}^{+}-$ $\mathrm{Cl}^{-}$composition (Fig. 4), a relatively large interval of temperatures (from 18 to $34^{\circ} \mathrm{C}$ ) and high salinity (TDS from 14.5 to $17.4 \mathrm{~g} / \mathrm{L}$ ). Besides the high $\mathrm{Na}^{+}$and $\mathrm{Cl}^{-}$concentrations (up to 5590 and $8590 \mathrm{mg} / \mathrm{L}$, respectively), these waters showed the highest concentrations of the other main dissolved species ( $\mathrm{SO}_{4}^{2-}$ from 1340 to $1580 \mathrm{mg} / \mathrm{L} ; \mathrm{HCO}_{3}^{-}$from 617 to $702 \mathrm{mg} / \mathrm{L} ; \mathrm{Ca}^{2+}$ from 538 to $662 \mathrm{mg} / \mathrm{L} ; \mathrm{Mg}^{2+}$ from 101 to $142 \mathrm{mg} / \mathrm{L} ; \mathrm{K}^{+}$from 119 to $145 \mathrm{mg} / \mathrm{L}$ ).

(2) Intermediate Salinity (hereafter $I S$ ) waters, which include samples from \#11 to \#22 (Table 1). They are partly resembling the $H S$ waters since they are $\mathrm{Na}^{+}-\mathrm{Cl}^{-}$in composition (Fig. 4) with temperatures from 16 to $26.9^{\circ} \mathrm{C}$. However, they can be distinguished for their lower salinity (TDS from 2.74 to $11 \mathrm{~g} / \mathrm{L})$.

(3) Low Salinity (hereafter $L S$ ) waters, which comprise samples from \#23 to \#31 (Table 1). They have a $\mathrm{Ca}^{+}-\mathrm{HCO}_{3}^{-}$composition, with the only exception of two $\mathrm{Na}^{+}-\mathrm{Cl}^{-}$waters (\#23 and \#31; Fig. 4), and the lowest TDS values $(\leqslant 1.11 \mathrm{~g} / \mathrm{L})$ and temperature $\left(\leqslant 16^{\circ} \mathrm{C}\right)$.

With a few exceptions, minor elements showed contents consistent with the main composition. The HS waters had indeed the highest $\mathrm{F}^{-}$(up to $7.5 \mathrm{mg} / \mathrm{L}$ ), $\mathrm{Br}^{-}$(up to $3.3 \mathrm{mg} / \mathrm{L}$ ), B (up to $3.3 \mathrm{mg} /$ $\mathrm{L}$ ), $\mathrm{Li}^{+}$(up to $4.9 \mathrm{mg} / \mathrm{L}$ ), $\mathrm{SiO}_{2}$ (up to $40 \mathrm{mg} / \mathrm{L}$ ) and $\mathrm{Sr}^{2+}$ (up to $12 \mathrm{mg} / \mathrm{L}$ ) concentrations. Conversely, the concentrations of $\mathrm{NO}_{3}^{-}$, ranging from 0.09 to $25 \mathrm{mg} / \mathrm{L}$, did not show significant differences among the three groups.

Among the measured trace elements (Table 2), $\mathrm{Rb}$ (up to $1100 \mu \mathrm{g} / \mathrm{L}$ ) and Cs (up to $770 \mu \mathrm{g} / \mathrm{L}$ ) showed the highest concentrations, which are positively correlated to those of TDS (not shown). $\mathrm{Fe}_{\text {tot }}$ and Mn contents in the $H S$ waters ranged from $<5$ to 330 and from $<0.1$ to $450 \mu \mathrm{g} / \mathrm{L}$, respectively, i.e. up to three orders of magnitude higher than the IS and $L S$ groups. Barium and $\mathrm{Zn}$ had relatively high concentrations (up to 50 and $42 \mu \mathrm{g} / \mathrm{L}$, respectively), with no significant differences among the three groups. A similar behavior was also shown by other trace species present at low concentrations, such as Al (up to $1.1 \mu \mathrm{g} / \mathrm{L}$ ), Sb (up to $0.7 \mu \mathrm{g} / \mathrm{L}$ ), As (up to $4.3 \mu \mathrm{g} / \mathrm{L}$ ), Co (up to $1.5 \mu \mathrm{g} / \mathrm{L}$ ), Cr (up to $2.6 \mu \mathrm{g} / \mathrm{L}$ ), Cu (up to $3.9 \mu \mathrm{g} / \mathrm{L}$ ) and $\mathrm{Ni}$ (up to $14 \mu \mathrm{g} / \mathrm{L}$ ).

Table 2

Trace elements (in $\mu \mathrm{g} / \mathrm{L}$ ) of the studied waters from Montecatini Terme.

\begin{tabular}{|c|c|c|c|c|c|c|c|c|c|c|c|c|c|c|c|}
\hline & & $\mathrm{Al}$ & $\mathrm{Sb}$ & As & $\mathrm{Ba}$ & Cs & Co & $\mathrm{Cr}$ & $\mathrm{Cu}$ & $\mathrm{Fe}_{\text {tot }}$ & $\mathrm{Mn}$ & $\mathrm{Ni}$ & $\mathrm{Rb}$ & $\mathrm{Zn}$ & Group \\
\hline 1 & Cratere Grocco & 0.3 & 0.3 & 0.7 & 39 & 500 & 1.2 & 0.1 & 0.8 & 5 & 60 & 0.5 & 920 & 4.4 & HS \\
\hline 2 & Savi & 1.1 & 0.4 & 2.9 & 50 & 670 & 1.4 & 0.2 & 1.1 & 180 & 93 & 0.1 & 1100 & 21 & HS \\
\hline 3 & Leopoldina Nuova & 0.5 & 0.1 & 2.9 & 45 & 830 & 1.4 & $<0.1$ & 3.9 & 65 & 46 & 14 & 1090 & 42 & HS \\
\hline 4 & Leopoldina Vecchia & 0.8 & 0.3 & 2.4 & 44 & 820 & 1.5 & $<0.1$ & 1.8 & 25 & 46 & 8 & 1070 & 19 & HS \\
\hline 5 & Campo & 0.6 & 0.7 & 4.3 & 39 & 440 & 1.4 & 0.1 & 0.2 & 330 & 100 & $<0.1$ & 1020 & 18 & HS \\
\hline 6 & Regina & 0.3 & 0.6 & 2.4 & 36 & 770 & 1.5 & $<0.1$ & 1.8 & 300 & 100 & 0.2 & 1120 & 16 & HS \\
\hline 7 & La Salute & 0.4 & 0.4 & 0.7 & 46 & 400 & 1.4 & 0.1 & 0.9 & 57 & 170 & $<0.1$ & 970 & 3.5 & HS \\
\hline 9 & Grotta & 0.1 & 0.3 & 0.5 & 32 & 500 & 1.3 & 0.1 & 0.6 & $<5$ & 0.6 & $<0.1$ & 1000 & 23 & HS \\
\hline 10 & Tamerici (s) & 0.4 & 0.6 & 0.3 & 38 & 320 & 1.4 & 0.1 & 1.0 & 8 & 450 & 0.3 & 940 & 5.1 & HS \\
\hline 12 & Tettuccio & 0.4 & 0.3 & 1.3 & 37 & 420 & 1 & 0.1 & 0.8 & $<5$ & 3.7 & 0.4 & 660 & 6.6 & IS \\
\hline 15 & Papo 1 & 0.2 & 0.2 & 1.0 & 31 & 190 & 0.7 & 0.1 & 0.5 & $<5$ & 0.4 & 0.1 & 370 & 6.9 & IS \\
\hline 19 & Giulia & 0.3 & $<0.1$ & 1.2 & 38 & 220 & 0.5 & 0.1 & $<0.1$ & $<5$ & 0.5 & $<0.1$ & 300 & 4.3 & IS \\
\hline 20 & Rinfresco & 0.3 & 0.2 & 1.0 & 42 & 170 & $<0.1$ & $<5$ & $<0.1$ & $<5$ & $<0.1$ & $<0.1$ & 240 & $<5$ & IS \\
\hline 22 & Padulette 1 & 0.5 & 0.1 & 0.7 & 46 & 100 & 0.4 & 0.2 & 1.0 & $<5$ & 0.3 & 0.1 & 190 & 6.4 & IS \\
\hline 25 & Tenente & 0.2 & $<0.1$ & 0.1 & 36 & $<1$ & 0.2 & 0.2 & 0.7 & $<5$ & $<0.1$ & $<0.1$ & 0.8 & $<0.1$ & LS \\
\hline 26 & Maona Media & 0.6 & $<0.1$ & 0.2 & 50 & $<1$ & 0.2 & 0.7 & 0.1 & $<5$ & 0.2 & $<0.1$ & 0.9 & $<0.1$ & LS \\
\hline 31 & Galassi & 1.0 & 0.1 & $<0.1$ & 25 & $<1$ & 0.1 & 2.6 & $<0.1$ & $<5$ & 0.3 & 1.1 & 1.3 & 3.3 & LS \\
\hline
\end{tabular}


Table 3

$\delta^{18} \mathrm{O}-\mathrm{H}_{2} \mathrm{O}$ and $\delta \mathrm{D}-\mathrm{H}_{2} \mathrm{O}$ ratios (\%o vs. $\mathrm{V}-\mathrm{SMOW}$ ), $\delta^{13} \mathrm{C}_{\mathrm{TDIC}}$ ratios (\%o vs. V-PDB) and TU values of the studied waters from Montecatini Terme.

\begin{tabular}{|c|c|c|c|c|c|c|c|c|}
\hline & & $\begin{array}{l}\delta^{18} \mathrm{O}- \\
\mathrm{H}_{2} \mathrm{O}\end{array}$ & $\begin{array}{l}\mathrm{DD}- \\
\mathrm{H}_{2} \mathrm{O}\end{array}$ & $\begin{array}{l}\delta^{34} \mathrm{~S}- \\
\mathrm{SO}_{4}\end{array}$ & $\begin{array}{l}\delta^{13} \mathrm{C}- \\
\text { TDIC }\end{array}$ & $\begin{array}{l}\delta^{13} C_{-} \\
\text {TDIC calc }\end{array}$ & $\mathrm{TU}$ & Group \\
\hline 1 & $\begin{array}{l}\text { Cratere } \\
\text { Grocco }\end{array}$ & -5.5 & -38.4 & 15.7 & -1.67 & & & $\mathrm{HS}$ \\
\hline 2 & Savi & -6.7 & -41.2 & & -2.43 & & & HS \\
\hline 3 & $\begin{array}{l}\text { Leopoldina } \\
\text { Nuova }\end{array}$ & -6.6 & -42.1 & 15.6 & -1.07 & -3.11 & 2 & HS \\
\hline 4 & $\begin{array}{l}\text { Leopoldina } \\
\text { Vecchia }\end{array}$ & -6.5 & -40.6 & & -0.63 & & & HS \\
\hline 5 & Campo & -6.6 & -42.3 & & -3.04 & -2.54 & & HS \\
\hline 6 & Regina & -6.8 & -43.5 & 15.5 & -1.91 & -2.90 & & HS \\
\hline 7 & La Salute & -6.6 & -42.2 & & -2.49 & & & HS \\
\hline 8 & Masso & -7.5 & -49.7 & & & & & HS \\
\hline 9 & Grotta & -7.3 & -48.8 & & -1.88 & & & HS \\
\hline 10 & $\begin{array}{l}\text { Tamerici } \\
\text { (s) }\end{array}$ & -6.5 & -39.5 & & -2.37 & -3.44 & & HS \\
\hline 11 & Angelo & -7.2 & -55.1 & & & & & IS \\
\hline 12 & Tettuccio & -6.2 & -42.5 & 15.9 & -3.74 & & & IS \\
\hline 13 & La Torretta & -7.2 & -53.2 & & & & & IS \\
\hline 14 & $\begin{array}{l}\text { Tamerici } \\
(\mathrm{w})\end{array}$ & -6.5 & -42.3 & & & & & IS \\
\hline 15 & Papo 1 & -6.7 & -40.9 & & -5.51 & -4.89 & & IS \\
\hline 16 & Baragiola & -7.5 & -49.6 & & & & & IS \\
\hline 17 & Cipollo & -6.7 & -41.2 & & & & & IS \\
\hline 18 & Papo 2 & -6.6 & -41.1 & & & & & IS \\
\hline 19 & Giulia & -7.1 & -53.3 & & -5.16 & -5.05 & & IS \\
\hline 20 & Rinfresco & -7.5 & -49.3 & & -5.95 & -6.79 & & IS \\
\hline 21 & Padulette 2 & -6.8 & -44.5 & & & & & IS \\
\hline 22 & Padulette 1 & -6.8 & -43.3 & & -10.7 & -8.98 & & IS \\
\hline 23 & Lavandaia & -7.4 & -49.2 & & & & & LS \\
\hline 24 & Orsi & -6.6 & -41.1 & & & & & LS \\
\hline 25 & Tenente & -7.3 & -48.4 & & -14.0 & & & LS \\
\hline 26 & $\begin{array}{l}\text { Maona } \\
\text { Media }\end{array}$ & -6.4 & -38.4 & & -14.8 & & & LS \\
\hline 27 & Melosi & -7.5 & -49.4 & & & & 10 & LS \\
\hline 28 & Maona Alta & -6.4 & -38.2 & & & & & LS \\
\hline 29 & $\begin{array}{l}\text { Fonte } \\
\text { Becca }\end{array}$ & -7.9 & -53.4 & & & & & LS \\
\hline 30 & Lucchesi 1 & -7.3 & -48.7 & & & & & LS \\
\hline 31 & Galassi & -7.9 & -53.3 & & -18.8 & & 10 & LS \\
\hline
\end{tabular}

The $\delta^{18} \mathrm{O}-\mathrm{H}_{2} \mathrm{O}$ and $\delta \mathrm{D}-\mathrm{H}_{2} \mathrm{O}$ values ranged from -5.5 to -7.9 and from $-38.4 \%$ to $-55.1 \%$, respectively. Sulfur isotopes in $\mathrm{SO}_{4}^{2-}$, measured in three samples from the HS group (\#1, \#3, \#6) and one sample from IS group (\#12), were varying in a very narrow range and comprised between $15.5 \%$ and $15.9 \%$. The $\delta^{13} \mathrm{C}_{\mathrm{TDIC}}$ ratios in the $H S$ waters, ranging from $-0.63 \%$ to $-3.04 \%$, were significantly less negative with respect to those of both IS (from $-3.74 \%$ to $-10.7 \%$ ) and $L S$ waters (from $-14.0 \%$ to $-18.8 \%$ ) (Table 3).

The ${ }^{3} \mathrm{H}$ value measured in \#3 (HS group) was $2 \mathrm{TU}$, whereas those of \#27 and \#31 (LS group) were 10 TU.

\subsection{Chemical and isotopic $\left(\delta^{13} \mathrm{C}-\mathrm{CO}_{2}\right)$ compositions of dissolved gases}

The chemical composition of the dissolved gases $\left(\mathrm{CO}_{2}, \mathrm{~N}_{2}, \mathrm{Ar}\right.$, $\mathrm{CH}_{4}, \mathrm{O}_{2}$ and $\mathrm{Ne}$ expressed in $\mathrm{mmol} / \mathrm{L}$ ) is shown in Table 4, where the $\delta^{13} \mathrm{C}_{-} \mathrm{CO}_{2}$ values are also reported. $\mathrm{CO}_{2}$ was the main dissolved gas compound in the $H S$ and IS waters (from 1.82 to $4.77 \mathrm{mmol} / \mathrm{L}$ ), followed by $\mathrm{N}_{2}$ (from 0.30 to $0.78 \mathrm{mmol} / \mathrm{L}$ ). Sample \#11 was the only exception, since it showed comparable concentrations of $\mathrm{CO}_{2}$ and $\mathrm{N}_{2}(0.40 \mathrm{mmol} / \mathrm{L}$ and $0.70 \mathrm{mmol} / \mathrm{L}$, respectively). The contents of $\mathrm{CH}_{4}, \mathrm{Ar}$ and $\mathrm{Ne}$ were in a relatively narrow range (from 0.00007 to 0.00057 , from 0.0071 to 0.019 and from 0.000033 to $0.0000087 \mathrm{mmol} / \mathrm{L}$, respectively), whereas $\mathrm{O}_{2}$ concentrations displayed a larger variation (from 0.0001 to $0.12 \mathrm{mmol} / \mathrm{L}$ ). The $\delta^{13} \mathrm{C}$ $\mathrm{CO}_{2}$ values $(-6.86 \%$ o to $-24.37 \%$ vs. $\mathrm{V}-\mathrm{PDB})$ tended to become more negative at decreasing TDS values.

\section{Discussion}

\subsection{Origin of waters}

The $\delta^{18} \mathrm{O}$ and $\delta \mathrm{D}$ values, which are consistent with those reported by Grassi et al. (2011), suggest that the Montecatini waters a meteoric origin (Fig. 5). The positive $\delta^{18} \mathrm{O}$-shift that characterizes the \#11, \#12, \#13 and \#19 thermal waters, not accompanied by a significant ${ }^{2} \mathrm{H}$ enrichment, is likely caused by water-rock interaction, whereas sample \#1, which is a small pond, is possibly affected by evaporation. The wide variations shown by the HS, IS, and LS samples, which distribute along the GMWL Global Meteoric Water Line (Craig, 1961), can be explained in terms of different altitudes of the recharge area. According to the $\delta^{18} \mathrm{O}$-elevation and $\delta \mathrm{D}$-elevation gradients (about $0.2 \quad \delta^{18} \mathrm{O} \%$ ol $100 \mathrm{~m}$ and from 5 to $10 \delta \mathrm{D} \% / 100 \mathrm{~m}$, respectively) proposed for central Italy by Minissale and Vaselli (2011), the latter ranges from $\sim 200 \mathrm{~m}$ a.s.l., where the Scaglia and limestone deposits outcrop, to $800 \mathrm{~m}$ a.s.l., i.e. the maximum elevation of the mountains surrounding the study area.

At a first approximation, the ${ }^{3} \mathrm{H}$ value of sample \#3 (Tritium Unit $=2$ ) would indicate that waters feeding the thermal emergences circulate at depth for a period of time up to $\sim 50$ years (Mussi et al., 1998). Nevertheless, mixing between a hydrothermal end-member with shallow waters, the latter (\#27 and \#31 cold springs) being characterized by a high ${ }^{3} \mathrm{H}$ value (10), can produce a significant underestimation of the calculated residence time for the uprising deep thermal fluids.

The chemical composition of the HS and IS waters, characterized by dominant $\mathrm{Na}^{+}$and $\mathrm{Cl}^{-}$with $\mathrm{Na}^{+} / \mathrm{Cl}^{-}$ratios $\sim 1$ (Fig. 6a), is likely produced by dissolution of halite from the Triassic evaporitic layers (Trevisan, 1955; Coradossi and Martini, 1965; Lugli, 2001). This hypothesis is confirmed by the high $\mathrm{Cl}^{-} / \mathrm{Br}^{-}$molar ratios (>5000; Fig. $6 \mathrm{~b}$ ) of the $H S$ and IS waters, typical of evaporite deposits and significantly higher than that of seawater or residual brines $(\leqslant 650)$ (McCaffrey et al., 1987; Fontes and Matray, 1993; Davis et al., 2001; Kloppmann et al., 2001; Gieskes and Mahn, 2007). Interaction of deep circulating waters (HS and $I S$ ) with anhydrite and carbonates (calcite and dolomite), all fundamental components of the Triassic evaporite formation (Coradossi and Martini, 1965), explains the relatively high $\mathrm{SO}_{4}^{2-}$ and $\mathrm{HCO}_{3}^{-}$concentrations (Table 1), as well as the $\mathrm{Ca}^{2+} / \mathrm{SO}_{4}^{2-}$ and $\mathrm{Ca}^{2+} / \mathrm{HCO}_{3}^{-}(\mathrm{mEq} / \mathrm{L})$ ratios ( $\sim 1$ and $\sim 3$, respectively; Fig. $6 \mathrm{c}$ and $\mathrm{d}$ ). The origin of the dissolved sulfate is further supported by the $\delta^{34} \mathrm{~S}-\mathrm{SO}_{4}$ values (Table 3), which are similar to the Triassic gypsum and anhydrite (16.0 $\pm 0.5 \%$ ) analyzed by Boschetti et al. (2005) from northern Tuscany and Triassic sulfates $(15.6 \pm 1.0 \%$ ) from different Italian sites (e.g. Cortecci et al., 1981, 2000; Dinelli et al., 1999; Boschetti et al., 2005).

Dedolomitization driven by anhydrite dissolution, which commonly affects reservoirs containing dolostones associated with gypsum layers (Back et al., 1983; Plummer et al., 1990; Capaccioni et al., 2001; Appelo and Postma, 2005), may also have a significant influence on the chemistry of these thermal waters. The $L S$ waters have $\mathrm{Ca}^{2+} / \mathrm{HCO}_{3}^{-}$(in equivalent units) fixed by stoichiometric dissolution of calcite (Fig. 6d). This feature implies that, when coupled with the low TDS values (Table 1 and Fig. 3), their chemistry is related to interaction with the carbonate fraction of the Macigno formation sandstones at shallow depth.

The relatively high concentrations of $\mathrm{B}$ and $\mathrm{Sr}^{2+}$ in $\mathrm{HS}$ and, at a minor extent, IS waters (Table 1) support the occurrence of rockwater interaction involving the Triassic rocks, since B is typically enriched in evaporite sequences (e.g. Degens et al., 1957), whereas $\mathrm{Sr}^{2+}$ is the main substituent for divalent ions, such as $\mathrm{Ca}^{2+}$ and $\mathrm{Mg}^{2+}$, in carbonates, with which it displays a positive correlation (not shown), and thus it tends to be enriched in the HS and IS waters. A positive correlation between $\mathrm{Sr}^{2+}$ and outlet 
Table 4

Chemical composition of dissolved gases $\left(\mathrm{CO}_{2}, \mathrm{~N}_{2}, \mathrm{Ar}, \mathrm{CH}_{4}, \mathrm{O}_{2}\right.$ and Ne expressed in mmol/L) and $\delta^{13} \mathrm{C}-\mathrm{CO}_{2}$ values of the studied waters from Montecatini Terme.

\begin{tabular}{|c|c|c|c|c|c|c|c|c|c|c|}
\hline & & $\mathrm{CO}_{2}$ & $\mathrm{~N}_{2}$ & $\mathrm{Ar}$ & $\mathrm{CH}_{4}$ & $\mathrm{O}_{2}$ & $\mathrm{Ne}$ & Tot. moles & $\delta^{13} \mathrm{C}-\mathrm{CO}_{2}$ & Group \\
\hline 3 & Leopoldina Nuova & 4.13 & 0.62 & 0.014 & 0.00026 & 0.0057 & 0.0000068 & 4.76 & -8.10 & HS \\
\hline 5 & Il Campo & 4.77 & 0.68 & 0.016 & 0.00041 & 0.123 & 0.0000080 & 5.60 & -8.05 & HS \\
\hline 6 & Regina & 5.16 & 0.77 & 0.017 & 0.00032 & 0.0003 & 0.0000085 & 5.94 & -8.10 & HS \\
\hline 8 & Masso & 2.68 & 0.47 & 0.011 & 0.00024 & 0.049 & 0.0000059 & 3.21 & -6.86 & HS \\
\hline 10 & Tamerici & 3.72 & 0.78 & 0.018 & 0.00035 & 0.0006 & 0.0000087 & 4.53 & -12.6 & HS \\
\hline 11 & Angelo & 0.40 & 0.70 & 0.017 & 0.00057 & 0.1012 & 0.0000079 & 1.22 & -10.3 & IS \\
\hline 13 & La Torretta & 1.88 & 0.30 & 0.0071 & 0.00013 & 0.042 & 0.0000041 & 2.23 & -10.0 & IS \\
\hline 15 & Papo 1 & 1.52 & 0.37 & 0.0087 & 0.00017 & 0.081 & 0.0000042 & 1.99 & -11.3 & IS \\
\hline 17 & Cipollo & 1.80 & 0.31 & 0.0071 & 0.00021 & 0.021 & 0.0000033 & 2.14 & -11.7 & IS \\
\hline 18 & Papo 2 & 1.82 & 0.34 & 0.0082 & 0.00012 & 0.0060 & 0.0000040 & 2.18 & -11.7 & IS \\
\hline 19 & Giulia & 1.90 & 0.54 & 0.013 & 0.00022 & 0.085 & 0.0000066 & 2.54 & -11.0 & IS \\
\hline 20 & Rinfresco & 2.08 & 0.48 & 0.011 & 0.00017 & 0.11 & 0.0000055 & 2.68 & -12.6 & IS \\
\hline 21 & Padulette 2 & 2.04 & 0.44 & 0.010 & 0.00020 & 0.022 & 0.0000049 & 2.51 & -16.7 & IS \\
\hline 22 & Padulette 1 & 1.83 & 0.37 & 0.0085 & 0.00013 & 0.0001 & 0.0000042 & 2.21 & -15.5 & IS \\
\hline 24 & Orsi & 0.075 & 0.64 & 0.016 & 0.00007 & 0.12 & 0.0000082 & 0.85 & -24.4 & LS \\
\hline \multicolumn{3}{|c|}{$\%$} & $\mathrm{CO}_{2}$ & \multicolumn{2}{|r|}{$\mathrm{N}_{2}$} & $\mathrm{Ar}$ & $\mathrm{CH}_{4}$ & \multicolumn{2}{|r|}{$\mathrm{O}_{2}$} & $\mathrm{Ne}$ \\
\hline 3 & \multicolumn{2}{|c|}{ Leopoldina Nuova } & 86.7 & \multicolumn{2}{|r|}{12.9} & 0.29 & 0.0055 & \multicolumn{2}{|r|}{0.12} & 0.00014 \\
\hline 5 & \multicolumn{2}{|l|}{ Il Campo } & 85.3 & \multicolumn{2}{|r|}{12.2} & 0.29 & 0.0072 & \multicolumn{2}{|r|}{2.20} & 0.00014 \\
\hline 6 & \multicolumn{2}{|l|}{ Regina } & 86.8 & \multicolumn{2}{|r|}{12.9} & 0.29 & 0.0054 & \multicolumn{2}{|r|}{0.006} & 0.00014 \\
\hline 8 & \multicolumn{2}{|l|}{ Masso } & 83.5 & \multicolumn{2}{|r|}{14.6} & 0.34 & 0.0074 & \multicolumn{2}{|r|}{1.52} & 0.00018 \\
\hline 10 & \multicolumn{2}{|l|}{ Tamerici } & 82.2 & \multicolumn{2}{|r|}{17.3} & 0.41 & 0.0078 & \multicolumn{2}{|r|}{0.013} & 0.00019 \\
\hline 11 & \multicolumn{2}{|l|}{ Angelo } & 32.7 & \multicolumn{2}{|r|}{57.6} & 1.35 & 0.047 & \multicolumn{2}{|r|}{8.28} & 0.00065 \\
\hline 13 & \multicolumn{2}{|l|}{ La Torretta } & 84.2 & \multicolumn{2}{|r|}{13.6} & 0.32 & 0.0056 & \multicolumn{2}{|r|}{1.90} & 0.00018 \\
\hline 15 & \multicolumn{2}{|l|}{ Papo 1} & 76.6 & \multicolumn{2}{|r|}{18.8} & 0.44 & 0.0086 & \multicolumn{2}{|r|}{4.06} & 0.00021 \\
\hline 17 & \multicolumn{2}{|l|}{ Cipollo } & 84.2 & & 14.5 & 0.33 & 0.0097 & & 0.98 & 0.00015 \\
\hline 18 & Papo 2 & & 83.7 & & 15.6 & 0.37 & 0.0056 & & 0.28 & 0.00018 \\
\hline 19 & Giulia & & 74.7 & & 21.4 & 0.50 & 0.0088 & & 3.33 & 0.00026 \\
\hline 20 & Rinfresco & & 77.7 & & 17.9 & 0.42 & 0.0063 & & 4.04 & 0.00021 \\
\hline 21 & Padulette 2 & & 81.2 & & 17.6 & 0.42 & 0.0080 & & 0.87 & 0.00020 \\
\hline 22 & Padulette 1 & & 83.0 & & 16.6 & 0.39 & 0.0058 & & 0.007 & 0.00019 \\
\hline 24 & Orsi & & 8.81 & & 75.2 & 1.90 & 0.0082 & & 14.1 & 0.00096 \\
\hline
\end{tabular}

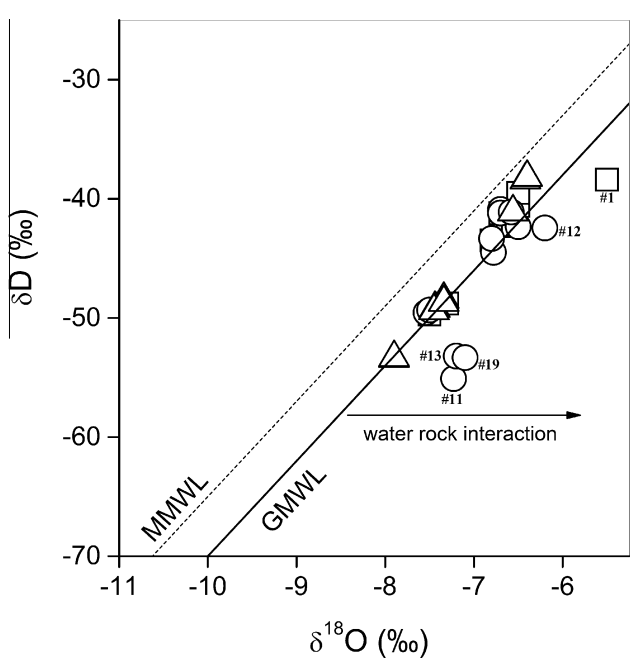

Fig. 5. $\delta \mathrm{D}-\delta^{18} \mathrm{O}$ diagram for the thermal and cold waters discharging in the Montecatini Terme area: (i) HS samples (squares); (ii) IS samples (circles) and (iii) LS samples (triangles). MMWL: Mediterranean Meteoric Water Line (Gat and Carmi, 1970); GMWL: Global Meteoric Water Line (Craig, 1961).

temperatures is also observed, suggesting that no significant precipitation of Ca-rich salts (e.g. gypsum and/or calcite) occurred, this process being favored at high temperatures and in response to variations of $\mathrm{CO}_{2}$ partial pressure (Marini and Chiodini, 1994; Minissale et al., 1997b). Similar considerations can be done for the $\mathrm{Rb}^{+}$concentrations (Table 2 ), since they are correlated to those of $\mathrm{K}^{+}$(not shown), these ions being characterized by similar ionic radius/charge ratio and, consequently, $\mathrm{Rb}^{+}$follows the fate of $\mathrm{K}^{+}$. The high $\mathrm{Sr}^{2+} / \mathrm{Rb}^{+}$ratios $(\sim 10)$ shown by all the thermal waters are significantly higher than those measured in cold waters circulating in the turbiditic sequence (Macigno Formation), Mesozoic limestone formations, and Palaeozoic basement (Boschetti et al., 2005), and can probably be attributed to dissolution of phyllosilicates minerals (illite and montmorillonite), a process that is favored by temperature. Cesium is considered the most mobile among the alkali metals when their respective concentrations in igneous and sedimentary rocks are considered. This is also supported by the $\mathrm{Rb} / \mathrm{Cs}$ ratios, which are $<3$, and similar to other thermal springs from Tuscany (Bencini, 1984). In thermal waters with temperatures between $40-140^{\circ} \mathrm{C}$, Cs varies between 10 and $900 \mu \mathrm{g} / \mathrm{L}$ (Mathurin et al., 2014 and references therein). The Montecatini thermal waters are enriched in Cs (up to $830 \mu \mathrm{g} / \mathrm{L}$ ) likely due to the fact that Cs, similarly to Rb, (Table 2) is associated with $\mathrm{K}^{+}$in halides.

Lithium, differently from the other alkali metals, is not allocated in the crystalline lattices of $\mathrm{Na}-\mathrm{K}$-silicates while in evaporitic environments it tends to be preferentially partitioned in the residual liquid phase. Lithium is considered a good pathfinder element in geothermal prospection and its behavior is mostly dictated by temperature, which favors water-rock interactions processes (e.g. Brondi et al., 1973). For this reason, its concentration results to be relatively high in thermal waters with respect to cold waters independently by the lithological features with which the waters are interacting. Prolonged rock-water interaction, related to longterm circulation pathways, favors $\mathrm{Li}^{+}$enrichments, as observed in the MTS waters. This is further supported by the low ${ }^{3} \mathrm{H}$ value measured in sample \#4.

$\mathrm{Fe}_{\text {tot }}, \mathrm{Mn}$ and $\mathrm{Zn}$ are likely related to the same deep source, being these elements contained in significant amounts in calcitedolomite rocks (Lugli et al., 2002), although their concentrations occasionally show strong variations, possibly caused by secondary (biogeochemical) processes occurring at different chemicalphysical conditions during the uprising of thermal fluids (e.g. Balistrieri et al., 1992, 1994; Viollier et al., 1995; Hongve, 1997). 


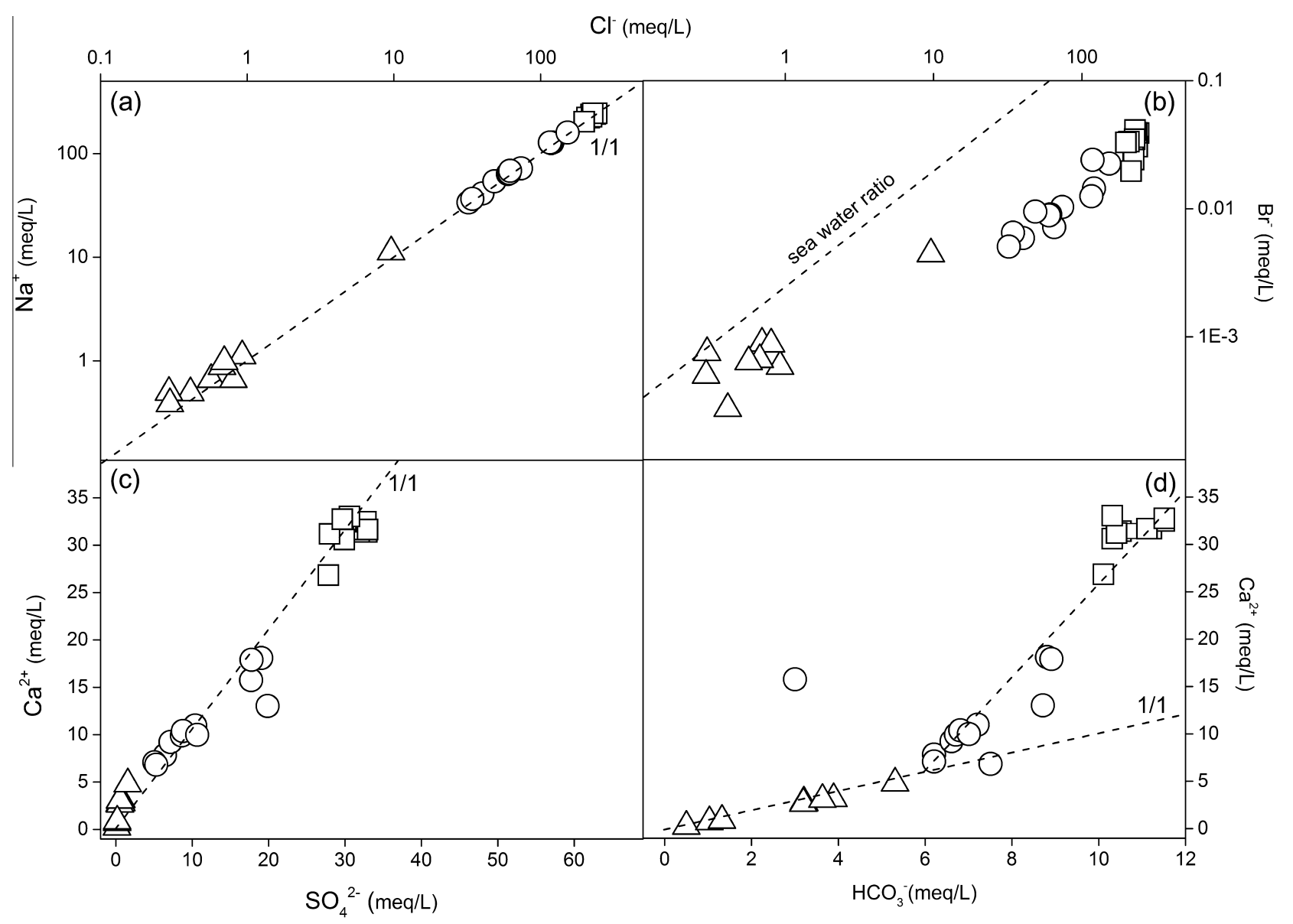

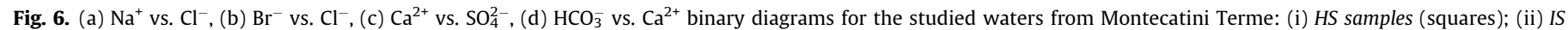
samples (circles) and (iii) LS samples (triangles).

Concentrations of $\mathrm{Al}, \mathrm{Co}, \mathrm{Cr}, \mathrm{Cu}$ and $\mathrm{Ni}$ are $<14 \mu \mathrm{g} / \mathrm{L}$, are in the range of thermal and cold waters (e.g. Göb et al., 2013). No significant concentrations were observed in MTS waters, likely because these elements are reactive in solution and tend to be removed since they participate to the formation of secondary minerals and/or and oxy-hydroxides. Barium contents, likely regulated by saturation with barite (or witherite), are $<50 \mu \mathrm{g} / \mathrm{L}$ and in the range for thermal springs reported by Göb et al. (2013). Arsenic and Sb contents in the studied waters are relatively low $(<4.3$ and $0.7 \mu \mathrm{g} / \mathrm{L}$, respectively). The low thermalism characterizing the Montecatini area does not allow an efficient mobilization of these two elements. They are indeed typically enriched in mineral and thermal waters (e.g. Hirner and Hippler, 2011 and references therein; Wilson et al., 2012), especially those related to volcanism and geothermal activity (e.g. Aiuppa et al., 2006) or to leaching processes of ore deposits hosting poly-metallic sulfides (e.g. Fu et al., 2010 and references therein).

The SI (Saturation Index) values of the main minerals of the Triassic evaporite sequence, computed using the PHREEQC v. 3.14 (Parkhurst and Appelo, 1999) software package (llnl database) considering the outlet temperatures of the waters, show that the HS and $I S$ waters are slightly saturated $(\geqslant 0)$ in calcite and oversaturated in dolomite (Table 5). The HS waters are also oversaturated in fluorite and at saturation in chalcedony. On the contrary, all waters are undersaturated in gypsum, anhydrite and halite.

\subsection{Origin of gases}

Dissolved gases basically consist of a mixture of $\mathrm{CO}_{2}$ and atmospheric components $\left(\mathrm{N}_{2}, \mathrm{Ar}, \mathrm{O}_{2}\right.$ and $\mathrm{Ne}$ ) with minor concentrations of $\mathrm{CH}_{4}$. At a regional scale, the peri-Tyrrhenian side of the Italian Peninsula, including the Montecatini area, is characterized by $\mathrm{CO}_{2}$-rich fluids discharges whose chemistry is intimately depending on water-rock interaction processes involving the Mesozoic limestone units of the Tuscan sedimentary series (e.g. Minissale, 2004). In this environment, $\mathrm{CO}_{2}$ is produced from (i) mantle degassing and (ii) thermochemical processes on the carbonate rich Mesozoic and Paleozoic formations (Chiodini et al., 1995a; Minissale et al., 1997a, 2000). However, the $\delta^{13} \mathrm{C}_{-} \mathrm{CO}_{2}$ values measured in the Montecatini thermal waters $(\leqslant-8.1 \%$ vs. V-PDB; Table 4) are significantly lower with respect to those expected for $\mathrm{CO}_{2}$ produced by both thermometamorphic reaction on limestone (from $-2 \%$ to $+2 \%$ vs. V-PDB; Craig, 1963) and mantle-related fluids (from $-3 \%$ to $-7 \%$ vs. V-PDB; Javoy et al., 1982; Kyser, 1986). These data are also not consistent with those characterizing the $\mathrm{CO}_{2}$ discharges from the central Italy and related to the so-called Tuscan-Roman Degassing Structure (TRDS; Chiodini et al., 1995a; Frondini et al., 2008). To provide insights into the origin of dissolved $\mathrm{CO}_{2}$ in the waters of the study area, the $\delta^{13} \mathrm{C}_{-} \mathrm{CO}_{2}$ values (Table 4 ) were used to compute the theoretical $\delta^{13} \mathrm{C}$-TDIC values $\left(\delta^{13} \mathrm{C}\right.$-TDIC calc) produced by the transformation of $\mathrm{CO}_{2}$ into $\mathrm{HCO}_{3}^{-}$(Mook et al., 1974), as follows:

$$
\begin{aligned}
\delta^{13} \mathrm{C}-\mathrm{TDIC} \text { calc }= & \left(\delta^{13} \mathrm{C}^{-\mathrm{CO}_{2}} *\left[\mathrm{CO}_{2}\right]+\delta^{13} \mathrm{C}-\mathrm{HCO}_{3}^{-}\right. \\
& \left.*\left[\mathrm{HCO}_{3}^{-}\right]\right) /\left(\left[\mathrm{HCO}_{3}^{-}\right]+\left[\mathrm{CO}_{2}\right]\right)
\end{aligned}
$$

where $\left[\mathrm{CO}_{2}\right]$ and $\left[\mathrm{HCO}_{3}^{-}\right]$indicate molalities, whereas the $\mathrm{CO}_{3}^{2-}$ concentrations were not considered since they were negligible due to the relatively low measured $\mathrm{pH}$ values (Table 1 ). Isotopic fractionation caused by the reaction between dissolved $\mathrm{CO}_{2}$ and $\mathrm{HCO}_{3}^{-}$, at the 
Table 5

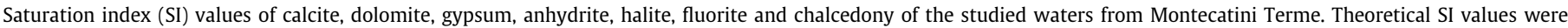
computed using the PHREEQC v. 3.14 (Parkhurst and Appelo, 1999) software package (llnl database).

\begin{tabular}{|c|c|c|c|c|c|c|c|c|c|}
\hline & & Gypsum & Anhydrite & Calcite & Dolomite & Halite & Fluorite & Chalcedony & Group \\
\hline 1 & Cratere Grocco & -0.49 & -0.57 & 0.41 & 1.55 & -3.15 & 0.39 & 0.03 & HS \\
\hline 2 & Savi & -0.47 & -0.62 & 0.33 & 1.35 & -3.15 & 0.49 & 0.14 & HS \\
\hline 3 & Leopoldina Nuova & -0.49 & -0.57 & 0.17 & 1.05 & -3.16 & 0.44 & 0.09 & HS \\
\hline 4 & Leopoldina Vecchia & -0.50 & -0.58 & 0.18 & 1.08 & -3.17 & 0.41 & -0.05 & HS \\
\hline 5 & Campo & -0.51 & -0.67 & 0.33 & 1.37 & -3.15 & 0.43 & 0.21 & HS \\
\hline 6 & Regina & -0.48 & -0.62 & 0.12 & 0.94 & -3.18 & 0.49 & 0.04 & HS \\
\hline 7 & La Salute & -0.47 & -0.68 & 0.36 & 1.38 & -3.18 & 0.36 & 0.26 & HS \\
\hline 8 & Masso & -0.51 & -0.75 & 0.64 & 2.03 & -3.20 & 0.52 & n.d. & HS \\
\hline 9 & Grotta & -0.50 & -0.74 & 0.46 & 1.57 & -3.21 & 0.56 & 0.25 & HS \\
\hline 10 & Tamerici & -0.55 & -0.80 & 0.39 & 1.43 & -3.26 & 0.49 & 0.36 & HS \\
\hline 11 & Angelo & -0.82 & -1.06 & 0.33 & 1.32 & -3.46 & -0.14 & & IS \\
\hline 12 & Tettuccio & -0.73 & -0.90 & 0.19 & 1.03 & -3.67 & -0.08 & -0.08 & IS \\
\hline 13 & La Torretta & -0.81 & -1.01 & 0.23 & 1.12 & -3.65 & -0.15 & & IS \\
\hline 14 & Tamerici & -0.87 & -1.11 & 0.49 & 1.62 & -3.65 & -0.31 & & IS \\
\hline 15 & Papo 1 & -1.20 & -1.38 & 0.09 & 0.81 & -4.07 & -0.82 & -0.10 & IS \\
\hline 16 & Baragiola & -1.09 & -1.32 & 0.23 & 1.07 & -4.13 & -0.74 & & IS \\
\hline 17 & Cipollo & -1.08 & -1.26 & 0.06 & 0.72 & -4.19 & -0.79 & & IS \\
\hline 18 & Papo 2 & -1.10 & -1.29 & 0.22 & 1.04 & -4.20 & -0.80 & & IS \\
\hline 19 & Giulia & -1.17 & -1.33 & 0.23 & 1.08 & -4.36 & -1.17 & -0.13 & IS \\
\hline 20 & Rinfresco & -1.31 & -1.47 & 0.07 & 0.72 & -4.54 & -1.19 & -0.14 & IS \\
\hline 21 & Padulette 2 & -1.33 & -1.56 & -0.22 & 0.13 & -4.64 & -1.24 & & IS \\
\hline 22 & Padulette 1 & -1.36 & -1.59 & 0.29 & 1.11 & -4.70 & -1.37 & -0.02 & IS \\
\hline 23 & Lavandaia & -1.77 & -2.04 & -0.17 & -0.05 & -5.64 & -2.75 & & LS \\
\hline 24 & Orsi & -2.14 & -2.42 & 0.28 & 1.35 & -7.61 & -2.53 & & LS \\
\hline 25 & Tenente & -2.26 & -2.54 & 0.40 & 1.60 & -7.78 & -2.75 & 0.00 & LS \\
\hline 26 & Maona Media & -2.17 & -2.45 & -0.03 & 0.68 & -7.90 & -3.19 & 0.03 & LS \\
\hline 27 & Melosi & -2.31 & -2.60 & -0.18 & 0.42 & -7.85 & -3.09 & & LS \\
\hline 28 & Maona Alta & -2.33 & -2.62 & 0.05 & 0.85 & -8.05 & -2.56 & & LS \\
\hline 29 & Fonte Becca & -3.09 & -3.41 & -1.40 & -2.00 & -8.51 & -3.82 & & LS \\
\hline 30 & Lucchesi 1 & -3.12 & -3.44 & -0.95 & -1.25 & -8.45 & -4.28 & & LS \\
\hline 31 & Galassi & -3.66 & -3.96 & -2.98 & -4.81 & -8.27 & -4.88 & 0.01 & LS \\
\hline
\end{tabular}

water outlet temperature, can be quantified by the $\varepsilon_{2}$ enrichment factor (Mook et al., 1974), as follows:

$\varepsilon_{2}=\delta^{13} \mathrm{C}-\mathrm{HCO}_{3}^{-}-\delta^{13} \mathrm{C}-\mathrm{CO}_{2}=9483 / T(\mathrm{~K})-23.9$

Therefore, by combining Eqs. (2) and (3) the relation between $\delta^{13} \mathrm{CTDIC}_{\text {calc }}$ and $\delta^{13} \mathrm{C}^{-} \mathrm{CO}_{2}$ is:

$\delta^{13} \mathrm{C}-\mathrm{TDIC}$ calc $=\delta^{13} \mathrm{C}-\mathrm{CO}_{2}+\varepsilon_{2} *\left[\mathrm{HCO}_{3}^{-}\right] /\left(\left[\mathrm{HCO}_{3}^{-}\right]+\left[\mathrm{CO}_{2}\right]\right)$

Results from Eq. (4) are in a good agreement with the $\delta^{13} \mathrm{C}$-TDIC values (Table 3 ), indicating that the isotopic equilibrium between $\mathrm{CO}_{2}$ and $\mathrm{HCO}_{3}^{-}$is attained. Therefore, the trend shown by water samples in the $\delta^{13} \mathrm{C}$-TDIC vs. $\mathrm{HCO}_{3}^{-}$diagram (Fig. 7) is the evidence that the carbon isotopic signatures of $\mathrm{CO}_{2}$ and TDIC of the Montecatini waters are controlled by mixing of deep-originated fluids with a shallow (organic) source showing the typical $\delta^{13} \mathrm{C}$ values of biogenic gases (O'Leary, 1988; Hoefs, 2008).

This implies that a significant $\mathrm{CO}_{2}$ fraction in the $H S$ waters, whose $\delta^{13} \mathrm{C}_{-} \mathrm{CO}_{2}$ values cannot represent the crustal/mantle end-member, is biogenic. However, we cannot exclude that precipitation of calcite and dolomite, possibly occurring during the uprising of thermal fluids, which are oversaturated in these minerals (Table 5), also contributes to produce a ${ }^{12} \mathrm{C}$-enrichment in both dissolved $\mathrm{CO}_{2}$ and $\mathrm{HCO}_{3}^{-}$. This also could explain the relatively low concentrations of $\mathrm{CH}_{4}$ (Table 4 ), a gas compound typically coupled with biogenic $\mathrm{CO}_{2}$. The origin of $\mathrm{CH}_{4}$ in gas discharges from sedimentary environments is indeed commonly related to microbial metabolic and biosynthetic activity and/or thermogenic degradation of pre-existing organic matter (e.g. Schoell, 1980, 1988; Whiticar et al., 1986; Galimov, 1988; Welhan, 1988). At a first approximation, the $\delta^{13} \mathrm{C}_{-} \mathrm{CH}_{4}$ values can provide insights to distinguish these two possible $\mathrm{CH}_{4}$ sources (e.g. Whiticar, 1999; McCollom and Seewald, 2007), although a genetic classification based on this parameter may result erroneous due to the effects

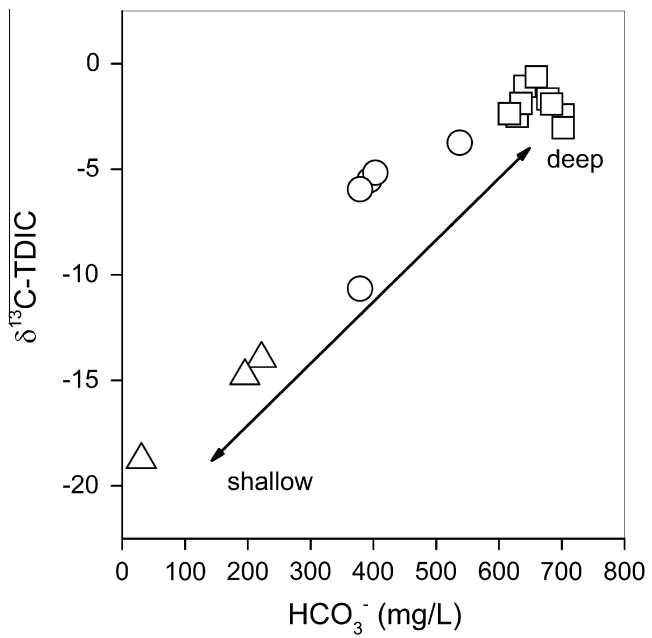

Fig. 7. $\delta^{13} \mathrm{C}$-TDIC vs. $\mathrm{HCO}_{3}^{-}$binary diagram for the studied waters from Montecatini Terme: (i) HS samples (squares); (ii) IS samples (circles) and (iii) LS samples (triangles).

of secondary processes occurring during gas migration, such as isotopic fractionation (Prinzhofer and Battani, 2003), secondary methanogenesis and anaerobic biodegradation (Pallasser, 2000; Etiope et al., 2009) processes. Owing to the extremely low $\mathrm{CH}_{4}$ concentrations, no $\delta^{13} \mathrm{C}_{-} \mathrm{CH}_{4}$ values are currently available for the MTS dissolved gases. Nevertheless, according to a recent investigation on the genetic mechanisms of $\mathrm{CH}_{4}$ from different (volcanic, hydrothermal, hypothermal) fluid discharges in central and southern Italy (Tassi et al., 2012) and in the absence of other geochemical evidences, the most likely origin for $\mathrm{CH}_{4}$ in the Montecatini-type fluids could be related to thermal degradation processes of preexisting organic matter buried in sediments. 
Atmospheric gases reach the deep fluid reservoir as dissolved phase in recharging meteoric waters, although the occurrence of $\mathrm{O}_{2}$ (Table 2) implies that some air is also added at shallow depth, i.e. in the last portion of the water uprising pathways. Both the $\mathrm{N}_{2} / \mathrm{Ar}(\sim 42)$ and $\mathrm{Ne} / \mathrm{Ar}$ ratios $(\sim 0.0005)$ are consistent with those

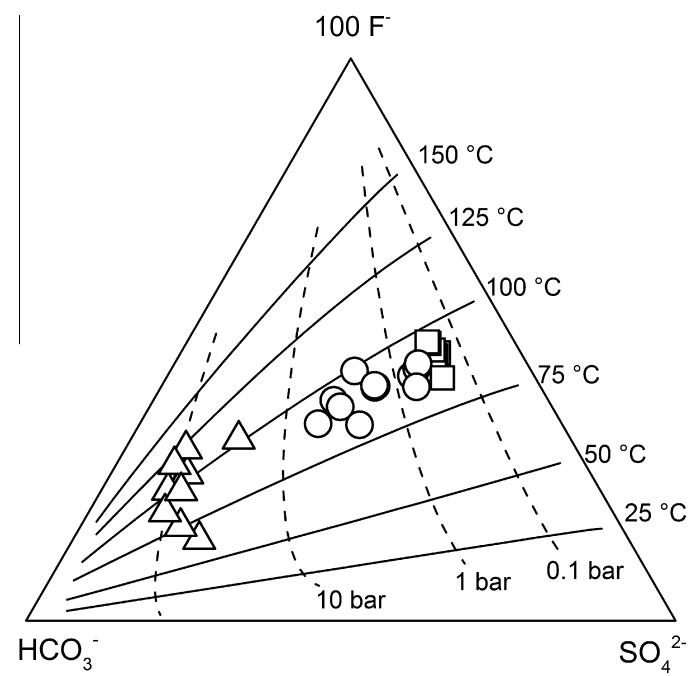

Fig. 8. Geothermometric estimations in the $\mathrm{F}^{-}-\mathrm{SO}_{4}^{2-}-\mathrm{HCO}_{3}^{-}$system (Chiodini et al., 1995b). of air-saturated water (ASW). Thus, no significant air contamination occurred during sampling. Moreover, this seems to exclude the presence of significant radiogenic Ar and extra-atmospheric $\mathrm{N}_{2}$. On the contrary, the $\mathrm{R} / \mathrm{Ra}$ value, where $\mathrm{R}$ is the measured ${ }^{3} \mathrm{He} /{ }^{4} \mathrm{He}$ ratio and $\mathrm{Ra}$ is the ${ }^{3} \mathrm{He} /{ }^{4} \mathrm{He}$ ratio in air (Mamyrin and Tolstikhin, 1984), shown by sample \#3 (0.28; Vaselli et al., unpublished data) seems to indicate a small, though significant $(<5 \%)$, contribution of mantle helium, although the helium isotopic signature characterizing the gas discharges in this sector of the Apennines is typical of crustal fluids (e.g. Minissale et al., 1997a, 2000; Minissale, 2004; Italiano et al., 2008; Chiodini et al., 2011; Bicocchi et al., 2013).

\subsection{Geothermometry}

Estimation of equilibrium temperatures based on the composition of the main cations, commonly used for aqueous solutions interacting with the typical authigenic assemblage of mediumto-high temperature $\left(150-300^{\circ} \mathrm{C}\right.$ ) hydrothermal systems (e.g. Giggenbach, 1988; Chiodini et al., 1991), cannot provide reliable results for low-temperature water reservoirs $\left(50-150{ }^{\circ} \mathrm{C}\right)$ hosted in carbonate-evaporite rocks. Marini et al. (1986) and Chiodini et al. (1995b) proposed a geothermometer to calculate equilibrium temperatures of hydrothermal systems characterized by mediumlow temperature hosted in carbonate-evaporite rocks from centralsouthern Italy. This geothermometer is based on the chemical equilibria involving calcite, dolomite, anhydrite and fluorite. According to this approach, a theoretical $\mathrm{T}-\mathrm{PCO}_{2}$ grid can be

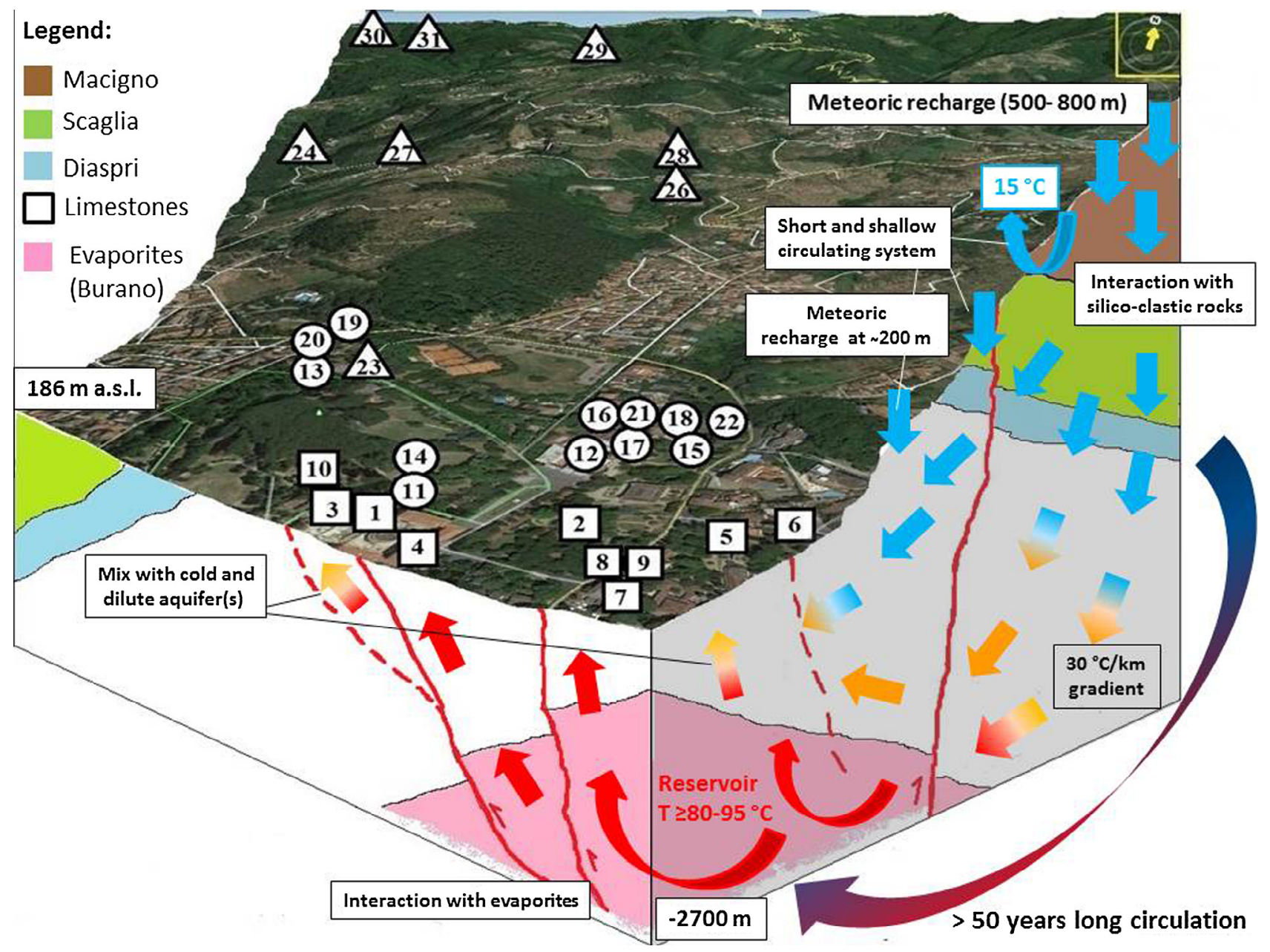

Fig. 9. Conceptual model of the fluid circulation in the Montecatini area. 
constructed in the $\mathrm{SO}_{4}^{2-}-\mathrm{F}^{-}-\mathrm{HCO}_{3}^{-}$ternary diagram. In Fig. 8, where the $\mathrm{T}-\mathrm{PCO}_{2}$ equilibrium lines were computed for $\mathrm{Cl}^{-}$concentrations $(0.1 \mathrm{~mol} / \mathrm{L})$ similar of those of the MTS waters (Table 1$)$, the $H S$ samples plot at $80-95^{\circ} \mathrm{C}$ and $P C_{2} \sim 0.5$ bars. The IS samples apparently equilibrated in the same temperature range and relatively high pressure conditions (from 0.5 to 8 bars of $\mathrm{CO}_{2}$ ), whereas the LS waters plot in a field corresponding to a wide temperature range at extremely high $P_{2} \mathrm{O}_{2}$ values ( $>10$ bars). This trend, apparently indicating an unreliable increase of pressure conditions at decreasing depth, is produced by the progressive increase of the $\mathrm{HCO}_{3}^{-} / \mathrm{SO}_{4}^{2-}$ and $\mathrm{HCO}_{3}^{-} / \mathrm{F}^{-}$ratios due to mixing processes between deep-originated $\mathrm{Na}^{+}-\mathrm{Cl}^{-}$waters with the $\mathrm{Ca}^{2+}-\mathrm{HCO}_{3}^{-}$shallow aquifer.

The equilibrium temperature of the $H S$ waters in the $\mathrm{SO}_{4}^{2-}-\mathrm{F}^{-}-\mathrm{HCO}_{3}^{-}$system is significantly higher than that calculated using the silica geothermometer (from 47 to $61^{\circ} \mathrm{C}$ ), assuming that chalcedony is the dominant silica mineral at depth (Arnòrsson, 1983). The disagreement of the two geothermometric estimations is likely due to the mixing between uprising thermal waters and shallow cold aquifers, a process (dilution) that is able to decrease the concentrations of solutes, including $\mathrm{SiO}_{2}$, with no effect on the $\mathrm{SO}_{4}^{2-} / \mathrm{F}^{-}$ratio (Fig. 8). Partial re-equilibration related to the cooling of uprising thermal fluids could also contribute to decrease the concentrations of $\mathrm{SiO}_{2}$, since silica precipitation has a relatively fast kinetics. Accordingly, the saturation index values of chalcedony for the $H S$ waters, although being positive, are significantly lower than those of fluorite.

\section{Conclusions}

The chemical and isotopic features of the MTS waters are mainly controlled by water-rock interaction processes involving meteoric water, permeating at depth from different elevations (200-800 m a.s.l.), and the Triassic evaporites of the Tuscan sedimentary series (Burano formation). Geothermometric estimations in the $\mathrm{F}^{-}-\mathrm{SO}_{4}^{2-}-\mathrm{HCO}_{3}^{-}$system suggest the occurrence of a main fluid reservoir at $T \geqslant 80-95^{\circ} \mathrm{C}$ and $\mathrm{PCO}_{2} \sim 0.5$ bars. Such a $\mathrm{CO}_{2}$ pressure is consistent with the $\mathrm{PCO}_{2}$ values estimated for thermal springs in central and southern Tuscany, where $\mathrm{CO}_{2}$ is basically supplied by a deep source (Minissale, 2004). This is apparently supporting the hypothesis that the Montecatini thermal waters, whose $\delta^{13} \mathrm{C}_{-} \mathrm{CO}_{2}$ and $\delta^{13} \mathrm{C}$-TDIC are lower than those expected for mantle/thermometamorphic $\mathrm{CO}_{2}$, are affected by isotopic fractionation caused by calcite precipitation, although mixing with organic gases may also occur at relatively shallow depth.

The measured ${ }^{3} \mathrm{H}$ values indicate that the Montecatini thermal waters are related to long fluid circulation patterns, likely $>50$ years. This would explain the longevity of this hydrothermal system, which has been exploited since centuries. Approaching the surface, the hot and saline waters mix with cold and dilute aquifer(s) fed by a short and shallow circulating system, whose chemistry is produced by interaction with silico-clastic rocks characterized by low solubility (Fig. 9). Assuming a geothermal gradient of $30^{\circ} \mathrm{C} / \mathrm{km}$ and an average rainwater temperature of $15^{\circ} \mathrm{C}$, the maximum depth of rainwater circulation is up to $\sim 2700 \mathrm{~m}$, i.e. within the Burano formation whose thickness in this region is likely $>2000 \mathrm{~m}$ (Colombetti and Zerrilli, 1987). The local stratigraphic and tectonic assessment, which drives the meteoric waters to the hydrothermal reservoir from a large catchment area, plays a fundamental role for the longevity of the Montecatini thermal spa, notwithstanding the large amount $\left(5.9 * 10^{6} \mathrm{~m}^{3} /\right.$ year in 2012, Montecatini Terme Ltd. pers. commun.) of the exploited thermal water.

At this regard, it is worth mentioning that previous studies (Brandi et al., 1967; Grassi et al., 2011) highlighted the occurrence (in the fifties and in 2009-2010) of seasonal variations in terms of electrical conductivity (E.C.) and $\mathrm{Cl}^{-}$. This variability was attributed to the hydraulic load provoked by the meteoric waters in the recharge areas, which would favor a higher mobilization of the deep circulating waters and at surface higher salinity waters are recovered differently to what occur during the dry season (piston effect, Brandi et al., 1967) when a decrease in electrical conductivity and $\mathrm{Cl}^{-}$is observed. These considerations suggest that MTS is clearly affected by the climatic conditions and a seasonal monitoring of the main parameters is recommended, should the Montecatini Terme Ldt. decide to increase the pumping rate of the thermal resources.

\section{Acknowledgements}

Many thanks are due to the Municipality of Montecatini Terme and the Montecatini Terme Ltd. for giving us the possibility to operate in the thermal area. A. Galassi, G. Lenzi, U. Lucchesi are warmly thanked for their assistance during the field-work and their information on the MTS. This work was supported by the Laboratories of Fluid and Rock Geochemistry and Stables Isotopes of the Department of Earth Sciences and CNR-IGG of Florence (FT and $\mathrm{OV}$, respectively). L. Marini and an anonymous reviewer are warmly thanked for their comments and suggestions that greatly improved an early version of the manuscript. Many thanks are due to A. Chiodi, R. Parigi and S. Venturi for their help during the field measurements.

\section{References}

Aiuppa, A., Avino, R., Brusca, L., Caliro, S., Chiodini, G., D’Alessandro, W., Favara, R., Federico, C., Ginevra, W., Inguaggiato, S., Longo, M., Pecoraino, G., Valenza, M., 2006. Mineral control of arsenic content in thermal waters from volcano-hosted hydrothermal systems: insights from Island of Ischia and Phlegrean Fields (Campanian Volcanic Province, Italy). Chem. Geol. 229, 313-330.

Appelo, C.A.J., Postma, D., 2005. Geochemistry, Groundwater and Pollution, second ed. Balkema, Rotterdam.

Arnòrsson, S., 1983. Chemical equilibria in Icelandic geothermal systems implications for chemical geothermal investigations. Geothermics 12, 119-128.

Arrigoni, P., Fico, L., Piovesana, F., Sommaruga, C., 1982. Industria termale e utilizzazione dei fluidi geotermici, l'esempio del progetto Bagno di Romagna. In Aquater s.p.a. (Eds.), S. Lorenzo in Campo, Italy, pp. 1-29.

Back, W. Hanshaw, B.B., Plummer, L.N., Rahn, P.H., Rightmire, C. T., Rubin, M., 1983. Process and rate of dedolomitization: mass transfer and ${ }^{14} \mathrm{C}$ dating in a regional carbonate aquifer. Geol. Soc. Am. Bull. 94, 1415-1429.

Balistrieri, L.S., Murray, J.W., Paul, B., 1992. The cycling of iron and manganese in the water column of Lake Sammamish, Washington. Limnol. Oceanogr. 37, 510528.

Balistrieri, L.S., Murray, J.W., Paul, B., 1994. The geochemical cycling of trace elements in a biogenic meromictic lake. Geochim. Cosmochim. Acta 58 (19), 3993-4008.

Bencini, A., 1984. Considerazioni sulla distribuzione geochimica del cesio nelle acque termali toscane. Rend. Soc. Min. Petrol. 39, 449-454, In Italian with English abstract.

Bencini, A., Duchi, V., 1981. Geochimical study of some waters from Porretta Terme, Bologna. Rend. Soc. Italy Mineral. Petrol. 38, 1189-1195 (in Italian).

Bencini, A., Duchi, V., Martini, M., 1977. Geochemistry of thermal springs of Tuscany (Italy). Chem. Geol. 19, 229-252.

Bertrami, R., Cameli, G.M., Lovari, F., Rossi, U., 1984. Discovery of Latera geothermal field. Seminar on Utilization of Geothermal Energy for Electric Power Production and Space Heating, Florence, Italy, pp. 1-18.

Bicocchi, G., Tassi, F., Bonini, M., Capecchiacci, F., Ruggieri, G., Buccianti, A., Burgassi, P., Vaselli, O., 2013. The high $\mathrm{pCO}_{2}$ Caprese reservoir (Northern Apennines, Italy): relationships between present- and paleo-fluid geochemistry and structural setting. Chem. Geol. 351, 40-56.

Boccaletti, M., Cerrina Feroni, A., Martinelli, P., Moratti, G., Plesi, G., Sani, F., 1992 Late Miocene-Quaternary compressive events in the Tyrrhenian side of the Northern Apennines. AnTec 6, 214-230.

Boschetti, T., Venturelli, G., Toscani, L., Barbieri, M., Mucchino, C., 2005. The Bagni di Lucca thermal waters (Tuscany, Italy): an example of $\mathrm{Ca}-\mathrm{SO}_{4}$ waters with high $\mathrm{Na} / \mathrm{Cl}$ and low Ca/SO 4 ratios. J. Hydrol. 307, 270-293.

Brandi, G.P., Fritz, P., Raggi, G., Squarci, P., Taffi, L., Tongiorgi, E., Trevisan, L., 1967. Idrogeologia delle Terme di Montecatini. In: Collana Scientifica Terme di Montecatini, 39. Pistoia pp. 50.

Brondi, M., Dall'Aglio, M., Vitrani, F., 1973. Lithium as pathfinder element in the large scale hydrothermal exploration for hydrothermal systems. Geothermics 2, $142-153$ 
Canavari, M., 1924. Le sorgenti di Montecatini in Val di Nievole di fronte alla Geologia. Giornale di geologia pratica 18, 1-4.

Cantini, P., Testa, G., Zanchetta, G., Cavallini, R., 2001. The Plio-Pleistocene evolution of extensional tectonics in northern Tuscany, as constrained by new gravimetric data from the Montecarlo Basin (lower Arno Valley, Italy). Tectonophysics 330, 25-43.

Capaccioni, B., Didero, M., Paletta, C., Salvatori, P., 2001. Hydrogeochemistry of groundwaters from carbonate formations with basal gypsiferous layers: an example from the Mt. Catria-Mt. Nerone ridge (Northern Appennines, Italy). J. Hydrol. 253, 14-26.

Carmignani, L., Decandia, F.A., Fantozzi, P.L., Lazzarotto, A., Liotta, D., Meccheri, M., 1994. Tertiary extensional tectonics in Tuscany (northern Apennines Italy) Tectonophysics 238, 295-315.

Carobbi, G., Cipriani, C., 1954. Ricerche geochimiche sulle acque minerali di Montecatini Terme (Pistoia). Rend. Soc. Mineral. Italy, X.

Cavarretta, G., Gianelli, G., Scandiffio, G., Tecce, F., 1985. Evolution of the Latera geothermal system II: metamorphic, hydrothermal mineral assemblages and fluid chemistry. J. Volcanol. Geotherm. Res. 26, 337-364.

Cerrina Feroni, A., Ottria, G., Ellero, A., 2004. The Northern Apennine, Italy: geological structure and transpressive evolution. In: Crescenti, U., D’Offizi, S., Merlino, S., Sacchi, L. (Eds.), Geology of Italy. Special Volume of the Italian Geological Society for the IGC 32 Florence, pp. 15-32.

Chiodini, G., Cioni, R., Guidi, M., Marini, L., 1991. Chemical geothermometry and geobarometry in hydrothermal solutions: a theoretical investigation based on a mineral-solution equilibrium model. Geochim. Cosmochim. Acta 55, 27092727.

Chiodini, G., Frondini, F., Ponziani, F., 1995a. Deep structures and carbon dioxide degassing in Central Italy. Geothermics 24, 81-94.

Chiodini, G., Frondini, F., Marini, L., 1995b. Theoretical geothermometers and pCO indicators for aqueous solutions coming from hydrothermal systems of medium-low temperature hosted in carbonate-evaporite rocks. Application to the thermal springs of the Etruscan Swell, Italy. Appl. Geochem. 10, 337-346.

Chiodini, G., Caliro, S. Cardellini, C., Frondini, F. Inguaggiato, S., Matteucci, F, 2011. Geochemical evidence for and characterization of $\mathrm{CO}_{2}$ rich gas sources in the epicentral area of the Abruzzo 2009 earthquakes. Earth Planet. Sci. Lett. 304 389-398.

Chiodini, G., Cardellini, C., Caliro, S., Chiarabba, C., Frondini, F., 2013. Advective heat transport associated with regional Earth degassing in central Apennine (Italy). Earth Planet. Sci. Lett. 373, 65-74.

Coleman, M.L., Sheperd, T.J., Rouse, J.E., Moore, G.R., 1982. Reduction of water with zinc for hydrogen isotope analysis. Anal. Chem. 54, 993-995.

Colombetti, A., Zerrilli, A., 1987. Prime valutazioni dello spessore dei gessi triassic mediante sondaggi elettrici verticali nella Valle del F. Secchia (Villa Minozzo_R.E.). Mem. Soc. Geol. Italy 39, 83-90.

Coradossi, N., Martini, M., 1965. Contributo allo studio geochimico delle acque di Montecatini Terme. Rend. Soc. Mineral. Italy 21, 67-90.

Cortecci, G., Reyes, E., Berti, G., Casati, P., 1981. Sulfur and oxygen isotopes in Italian marine sulphates of Permian and Triassic ages. Chem. Geol. 34, 65-79.

Cortecci, G., Dinelli, E., Civitavecchia, V., 2000. Isotopic and geochemical features of rocks from Punta delle Pietre Nere Gargano Peninsula, Southern Italy. Per. Miner. 69, 205-216.

Craig, H., 1961. Isotopic variations in meteoric waters. Science 133, 1702-1708.

Craig, H., 1963. The isotopic geochemistry of water and carbon in geothermal areas. In: Tongiorgi, E. (Eds.), Nuclear Geology on Geothermal Areas. Spoleto, C.N.R (Italian Council for Research), Rome, pp. 17-54.

Davis, S.N., Cecil, L.D., Zreda, M., Moysey, S., 2001. Chlorine-36, bromide, and the origin of spring water. Chem. Geol. 179, 3-16.

Degens, E.T., Williams, E.G., Keith, M.L., 1957. Environmental studies of Carboniferous sediments. Part I: Geochemical criteria for differentiating marine from fresh water shales. Am. Ass. Petr. Geol. Bull. 41, 2427-2455.

Dinelli, E., Testa, G., Cortecci, G., Barbieri, M., 1999. Stratigraphic and petrographic constraints to trace elements and isotope geochemistry of Messinian sulphates of Tuscany. Mem. Soc. Geol. Italy 54, 61-74.

Duchi, V., Minissale, A., Rossi, R., 1986. Chemistry of thermal springs in the Larderello geothermal region, southern Tuscany, Italy. Appl. Geochem. 1, 659667.

Epstein, S., Mayeda, T.K., 1953. Variation of the ${ }^{18} \mathrm{O} /{ }^{16} \mathrm{O}$ ratio in natural waters. Geochim. Cosmochim. Acta 4, 213-224.

Etiope, G., Feyzullayev, A., Milkov, A.V., Waseda, A., Mizobe, K., Sun, C.H., 2009. Evidence of subsurface anaerobic biodegradation of hydrocarbons and potentia secondary methanogenesis in terrestrial mud volcanoes. Mar. Petrol. Geol. 26, 1692-1703.

Evans, W.C., White, L.D., Rapp, J.B., 1998. Geochemistry of some gases in hydrothermal fluids from the southern San Juan de Fuca ridge. J. Geophys. Res. 15, 305-313.

Fazzuoli, M., Maestrelli Manetti, O., 1973. I nuclei mesozoici di Monsummano, Montecatini Terme e Marliana (Prov. di Pistoia). Mem. Soc. Geol. Italy 12 (1) 39-79.

Fontes, J.C., Matray, J.M., 1993. Geochemistry and origin of formation brines from the Paris Basin, France. Chem. Geol. 109, 177-200.

Frondini, F., 2008. Geochemistry of regional aquifer systems hosted by carbonateevaporite formations in Umbria and southern Tuscany (central Italy). Appl. Geochem. 23, 2091-2104.

Frondini, F., Caliro, S., Cardellini, C., Chiodini, G., Morgantini, N., Parello, F., 2008 Carbon dioxide degassing from Tuscany and Northern Latium (Italy). Global Planet. Change 61, 89-102.
Frondini, F., Caliro, S., Cardellini, C., Chiodini, G., Moegantini, N., 2009. Carbon dioxide degassing and thermal energy release in the Monte Amiata volcanicgeothermal area (Italy). Appl. Geochem. 24, 860-875.

Fu, Z., Wu, F., Amarasiriwardena, D., Mo, C., Liu, B., Zhu, J., Deng, Q., Liao, H., 2010. Antimony, arsenic and mercury in the aquatic environment and fish in a large antimony mining area in Hunan, China. Sci. Total Environ. 408, 3403-3410.

Funiciello, R., Mariotti, G., Parotto, M., Preite-Martinez, M., Tecce, F., Toneatti, R., Turi, B., 1979. Geology, mineralogy and stable isotope geochemistry of the Cesano geothermal field (Sabatini Mountains, Northern Latium, Italy). Geothermics 8, 55-73.

Galimov, E.M., 1988. Sources and mechanisms of formation of gaseous hydrocarbons in sedimentary rocks. Chem. Geol. 71, 77-95.

Gandin, A., Giamello, M., Guasparri, G., Mugnaini, S., Sabatini, G., 2000. The Calcare Cavernoso of the Montagnola senese (Siena Italy): mineralogical-petrographic and petrogenetic features. Mineral. Petr. Acta 43, 271-289.

Gat, J.R., Carmi, I., 1970. Evolution of the isotopic composition of atmospheric waters in the Mediterranean Sea area. J. Geophys. Res. 75, 3039-3048.

Gieskes, J.M., Mahn, C., 2007. Halide systematics in interstitial waters of ocean drilling sediment cores. Appl. Geochem. 22, 515-533.

Giggenbach, W.F., 1988. Geothermal solute equilibria. Derivation of $\mathrm{Na}-\mathrm{K}-\mathrm{Mg}-\mathrm{Ca}$ geoindicators. Geochim. Cosmochim. Acta 52, 2749-2765.

Göb, S., Loges, A., Nolde, N., Bau, M., Jacob, D.E., Markl, G., 2013. Major and trace element compositions (including REE) of mineral, thermal, mine and surface waters in SW Germany and implications for water-rock interaction. Appl. Geochem. 33, 127-152.

Grassi, S., Doveri, M., Ellero, A., Palmieri., F., Vaselli, L., Calvi., E., Trifirò, S, 2011. Studio dei sistemi termali di Montecatini e Monsummano Terme. Attuazione del protocollo d'intesa Regione/CNR Istituto di Geoscienze e Georisorse (IGG) di Pisa per il monitoraggio delle risorse termali (DGR $\left.n^{\circ} 1007 / 2207\right)$. On-line Final Report, May 2011 <http://www.regione.toscana.it/documents/10180/ 471469/studio+dei+sistemi+termali+di+montecatini+e+monsummano+terme. pdf/af4f04f2-5a03-41fb-ad2e-8a338274a76b>, p. 107 (in Italian).

Hirner, A., Hippler, J., 2011. Trace metal(loid)s (As, Cd, Cu, Hg, Pb, PGE, Sb, and Zn) and their species. In: "Treatise on Water Science", vol. 3: Acquatic chemistry and Biology, Wilderer, P (Ed.), pp. 31-57.

Hoefs, J., 2008. Stable Isotope Chemistry. Springer, Berlin, New York, pp. 260.

Hongve, D., 1997. Cycling of iron, manganese, and phosphate in a meromictic lake. Limnol. Oceanogr. 42, 635-647.

Italiano, F., Martinelli, G., Plescia, P., 2008. $\mathrm{CO}_{2}$ degassing over seismic areas: the role of mechanochemical production at the study case of Central Apennines. Pure App. Geophys. 165, 75-94.

Javoy, M., Pineau, F., Allègre, C.J., 1982. Carbon geodynamic cycle. Nature 300, 171 173.

Kloppmann, W., Négrel, P., Casanova, J., Klinge, H., Schelkes, K., Guerrot, C., 2001. Halite dissolution derived brines in the vicinity of a Permian salt dome $(\mathrm{N}$ German Basin). Evidence from boron, strontium, oxygen, and hydrogen isotopes. Geochim. Cosmochim. Acta 65 (22), 4087-4101.

Kyser, T.K., 1986. Stable isotope variations in the mantle. In: Valley, J.W., Taylor, H.P., O'Neil, J.R. (Eds.), Stable isotopes in high temperature geological processes. Rev. Mineral., vol. 16, pp. 141-164.

Lazzarotto, A., Sandrelli, F., Foresi, L.M., Mazzei, R., Salvatorini, G., Cornamusini, G. Pascucci, V., 2002. Note Illustrative della Carta Geologica d'Italia alla scala 1:50.000, Foglio 295, Pomarance. Serv. Geol. D'Italia, pp. 140.

Lugli, S., 2001. Timing of post-depositional events in the Burano Formation of the Secchia valley (Upper Triassic, Northern Apennines), clues from gypsumanhydrite transitions and carbonate metasomatism. Sediment. Geol. 140, 107122.

Lugli, S., Morteani, G., Blamart, D., 2002. Petrographic, REE, fluid inclusions and stable isotope study of magnesite from the Upper Triassic Burano Evaporites (Secchia Valley, northern Appennines): contributions from sedimentary, hydrothermal and metasomatic sources. Miner. Deposita 37, 480-494.

Mamyrin, B.A., Tolstikhin, I.N., 1984. Helium Isotopes in Nature. Elsevier, Amsterdam, 273 p.

Marini, L., Chiodini, G., 1994. The role of carbon dioxide in the carbonate-evaporite geothermal systems of Tuscany and Latium (Italy). Acta Vulcanol. 5, 95-104.

Marini, L., Chiodini, G., Cioni, R., 1986. New geothermometers for carbonateevaporite geothermal reservoirs. Geothermics 15, 77-86.

Martini, M., 1968. Studio del ciclo annuale della composizione delle acque di Montecatini Terme (Pistoia) e sua interpretazione. Atti Accad. Naz. Lincei. Rend. Sci. Fis. Mat. Nat. 44, 783-800.

Martinis, B., Pieri, M., 1963. Alcune notizie sulla formazione evaporitica del Triassico Superiore nell'Italia centrale e meridionale. Mem. Soc. Geol. Italy 4, 649-678.

Mathurin, F.A., Drake, H., Tullborg, E.-L., Berger, T., Peltola, P., Kalinowski, B.E., Aström, M.E., 2014. High cesium concentrations in groundwater in the upper $1.2 \mathrm{~km}$ of fractured crystalline rock - influence of groundwater origin and secondary minerals. Geochim. Cosmochim. Acta 132, 187-213.

McCaffrey, M.A., Lazar, B., Holland, H.D., 1987. The evaporation path of seawater and the coprecipitation of $\mathrm{Br}$ and $\mathrm{K}$ with halite. J. Sediment. Petrol. 57, 928-937.

McCollom, T.M., Seewald, J.S., 2007. Abiotic synthesis of organic compounds in deep-sea hydrothermal environments. Chem. Rev. 107, 382-401.

Minissale, A., 1991. The Larderello geothermal field: a review. Earth Sci. Rev. 31, $133-151$.

Minissale, A., 2004. Origin, transport and discharge of $\mathrm{CO}_{2}$ in central Italy. Earth Sci. Rev. 66, 89-141.

Minissale, A., Duchi, V., 1988. Geothermometry on fluids circulating in a carbonate reservoir in north-central Italy. J. Volcanol. Geotherm. Res. 35, 237-252. 
Minissale, A., Vaselli, O., 2011. Karst springs as "natural" pluviometers: constrains on the isotopic composition of rainfall in the Apennines of central Italy. Appl Geochem. 26, 838-852.

Minissale, A., Evans, W.C., Magro, G., Vaselli, O., 1997a. Multiple source components in gas manifestations from north-central Italy. Chem. Geol. 142, 175-192.

Minissale, A., Magro, G., Vaselli, O., Verrucchi, C., Perticone, I., 1997b. Geochemistry of water and gas discharges from the Mt. Amiata silicic complex and surrounding areas (central Italy). J. Volcanol. Geotherm. Res. 79, 223-251.

Minissale, A., Magro, G., Martinelli, G., Vaselli, O., Tassi, F., 2000. Fluid geochemical transect in the Northern Apennines (central-northern Italy): fluid genesis and migration and tectonic implications. Tectonophysics 319, 199-222.

Molli, G., 2008. Northern Apennine - Corsica orogenic system: an updated overview. Geol. Soc. Lond. Spec. Publ. 298, 413-442.

Mook, W.G., Bommerson, J.C., Staverman, W.H., 1974. Carbon isotope fractionation between dissolved bicarbonate and gaseous carbon dioxide. Earth Planet. Sci. Lett. 22, 169-176.

Mussi, M., Leone, G., Nardi, I., 1998. Isotopic geochemistry of natural waters from the Alpi Apuane-Garfagnana area Northern Tuscany, Italy. Miner. Petrogr. Acta 41, 163-178.

O’Leary, M.H., 1988. Carbon isotopes in photosynthesis. Bioscience 38, 328-336.

Pallasser, R.J., 2000. Recognising biodegradation in gas/oil accumulations through the $\delta^{13} \mathrm{C}$ compositions of gas components. Org. Geochem. 31, 1363-1373.

Parkhurst, D.L., Appelo, C.A.J., 1999. User's guide to PHREEQC (version 2) - a computer program for speciation, batch-reaction, one-dimensional transport, and inverse geochemical calculations. In: U.S. Geological Survey WaterResources Investigations Report, pp. 99-4259.

Patacca, E., Sartori, R., Scandone, P., 1990. Thyrrenian basin and Apenninic arcs: Kinematic relation since late Tortonian times. Mem. Soc. Geol. Italy 45, 425451.

Plummer, L.N., Busby, J.F., Lee, R.W., Hanshaw, B.B., 1990. Geochemical modelling in the Madison aquifer in parts of Montana, Wyoming and South Dakota. Water Resour. Res. 26, 1981-2014.

Prinzhofer, A.A., Battani, A., 2003. Gas isotopes tracing: an important tool for hydrocarbon exploration. Oil Gas Sci. Technol. 58 (2), 229-311.

Puccinelli, A., D’Amato Avanzi, G., Verani, M, Caredio, F., 2010. Carta geologica della Toscana - Foglio 262 - Pistoia. Regione Toscana. (In Italian).

Puxeddu, M., 1984. Structure and late cenozoic evolution of the upper lithosphere in southwest Tuscany (Italy). Tectonophysics 101, 357-382.

Romei, P., Capo, A., 2014: Osservatorio Turistico di Destinazione sostenibile e competitivo del Comune di Montecatini Terme. Report 2014. Università di Firenze, Dipartimento di Scienze economiche, Facoltà di Economia, pp. 22 (in Italian).

Romei, P., Becucci, C., Fanucchi, A., Pagni, G., 2012. Osservatorio Turistico di Destinazione sostenibile e competitivo del Comune di Montecatini Terme. Relazione Finale. Università di Firenze, Dipartimento di Scienze economiche, Facoltà di Economia, pp. 140 (in Italian).
Salata, G.G., Roelke, L.A., Cifuentes, L.A., 2000. A rapid and precise method for measuring stable carbon isotope ratios of dissolved inorganic carbon. Mar. Chem. 69, 153-161.

Schoell, M., 1980. The hydrogen and carbon isotopic composition of methane from natural gases of various origins. Geochim. Cosmochim. Acta 44, 649-661.

Schoell, M., 1988. Multiple origins of methane in the Earth. Chem. Geol. 71, 1-10.

Tassi, F., Vaselli, O., Luchetti, G., Montegrossi, G., Minissale, A., 2008. Metodo per la determinazione dei gas disciolti in acque naturali. Int. Rep., CNR-IGG, Florence, Italy, pp. 11 (in Italian).

Tassi, F., Vaselli, O., Tedesco, D., Montegrossi, G., Darrah, T., Cuoco, E., Mapendano, M.Y., Poreda, R., Delgado Huertas, A., 2009. Water and gas chemistry at Lake Kivu (DRC): geochemical evidence of vertical and horizontal heterogeneities in a multi-basin structure. Geochem. Geophys. Geosyst, vol. 10(2). http://dx.doi. org/10.1029/2008GC002191.

Tassi, F., Fiebig, J., Vaselli, O., Nocentini, M., 2012. Origins of methane discharging from volcanic-hydrothermal, geothermal and cold emissions in Italy. Chem. Geol. 310-311, 36-48.

Taylor, C.B., Roether, W., 1982. A uniform scale for reporting low-level tritium measurements in water. Int. J. Appl. Radiat. Isotopes 33, 377-382.

Trevisan, L., 1951. Una nuova ipotesi sull'origine della termalità di alcune sorgenti della Toscana. In. Min. 2, 41-42.

Trevisan, L., 1954. La nuova sorgente Leopoldina di Montecatini Terme e le condizioni geologiche del sottosuolo. Boll. Ingegn. II, 8-9.

Trevisan, L., 1955. Il Trias della Toscana e il problema del Verrucano triassico. Atti Soc. Toscana Sci. Nat. Series A LXII.

Vaselli, O., Tassi, F., Montegrossi, G., Capaccioni, B., Giannini, L., 2006. Sampling and analysis of volcanic gases. Acta Vulcanol. 18, 65-76.

Viollier, E., Jezequel, D., Michard, G., Pepe, M., Sarazin, G., Alberic, P., 1995. Geochemical study of a crater lake (Pavin Lake, France): trace-element behaviour in the monimolimnion. Chem. Geol. 125 (1-2), 61-72.

Welhan, J.A., 1988. Origins of methane in hydrothermal systems. Chem. Geol. 71, $183-198$.

Whitfield, M., 1978. Activity coefficients in natural waters. In: Pytkowicz, R.M. (Ed.) Activity Coefficients in Electrolyte Solutions. CRC Press, Boca Raton, Florida, pp. 153-300.

Whiticar, M.J., 1999. Carbon and hydrogen isotope systematic of bacterial formation and oxidation of methane. Chem. Geol. 161, 291-314.

Whiticar, M.J., Faber, E., Schoell, M., 1986. Biogenic methane formation in marine and freshwater environments: $\mathrm{CO}_{2}$ reduction vs. acetate fermentation-isotopic evidence. Geochim. Cosmochim. Acta 50, 693-709.

Wilson, N., Webster-Brown, J., Brown, K., 2012. The behaviour of antimony released from surface geothermal features in New Zealand. J. Volcanol. Geotherm. Res. 247-248, 158-167.

Zhang, J., Quay, P.D., Wilbur, D.O., 1995. Carbon isotope fractionation during gaswater exchange and dissolution of $\mathrm{CO}_{2}$. Geochim. Cosmochim. Acta 59, $107-$ 114. 